IZA DP No. 9160

Guns and Butter?

Fighting Violence with the Promise of Development

Gaurav Khanna

Laura Zimmermann

June 2015 


\title{
Guns and Butter? Fighting Violence with the Promise of Development
}

\author{
Gaurav Khanna \\ University of Michigan
}

Laura Zimmermann

University of Georgia

and IZA

\section{Discussion Paper No. 9160 \\ June 2015}

\author{
IZA \\ P.O. Box 7240 \\ 53072 Bonn \\ Germany \\ Phone: +49-228-3894-0 \\ Fax: +49-228-3894-180 \\ E-mail: iza@iza.org
}

\begin{abstract}
Any opinions expressed here are those of the author(s) and not those of IZA. Research published in this series may include views on policy, but the institute itself takes no institutional policy positions. The IZA research network is committed to the IZA Guiding Principles of Research Integrity.

The Institute for the Study of Labor (IZA) in Bonn is a local and virtual international research center and a place of communication between science, politics and business. IZA is an independent nonprofit organization supported by Deutsche Post Foundation. The center is associated with the University of Bonn and offers a stimulating research environment through its international network, workshops and conferences, data service, project support, research visits and doctoral program. IZA engages in (i) original and internationally competitive research in all fields of labor economics, (ii) development of policy concepts, and (iii) dissemination of research results and concepts to the interested public.
\end{abstract}

IZA Discussion Papers often represent preliminary work and are circulated to encourage discussion. Citation of such a paper should account for its provisional character. A revised version may be available directly from the author. 


\section{ABSTRACT \\ Guns and Butter? \\ Fighting Violence with the Promise of Development ${ }^{*}$}

There is growing awareness that development-oriented government policies may be an important counterinsurgency strategy, but existing papers are usually unable to disentangle various mechanisms. Using a regression-discontinuity design, we analyze the impact of one of the world's largest anti-poverty programs, India's NREGS, on the intensity of Maoist conflict. We find short-run increases of insurgency-related violence, police-initiated attacks, and insurgent attacks on civilians. We discuss how these results relate to established theories in the literature. The main mechanism consistent with the empirical patterns is that NREGS induces civilians to share more information with the state, improving police effectiveness.

JEL Classification: H12, H53, H56, I38

Keywords: public works program, National Rural Employment Guarantee Scheme, NREGA, NREGS, India, regression discontinuity design, terrorism, Naxalites, Maoists, conflict, insurgency, civil war

Corresponding author:

Laura Zimmermann

University of Georgia

Brooks Hall

310 Herty Drive

Athens, GA 30602

USA

E-mail: Ivzimmer@uga.edu

\footnotetext{
* We thank Achyuta Adhvaryu, Manuela Angelucci, Raj Arunachalam, Prashant Bharadwaj, Adi Dasgupta, James Fenske, Kishore Gawande, Devesh Kapur, Julien Labonne, Jacob Shapiro, Jeffrey Smith, Oliver Vanden Eynde, Dean Yang and participants at the Pacific Conference for Development Economics 2013, the Centre for Studies of African Economies Conference 2013, the Workshop on India's Maoist Insurgency at Princeton University, and the University of Michigan Development Seminar for valuable comments, feedback and suggestions. We also thank Melissa Trebil for excellent research assistantship.
} 


\section{Introduction}

Internal military conflicts between government troops and insurgents are common in many developing countries. Governments have traditionally relied heavily on military force, but there is a growing awareness that this alone may not be enough to end violence since insurgents often rely on the loyalty of the local population in their guerrilla tactics and recruit members from economically marginalized groups. In such situations, government anti-poverty programs are increasingly seen as a potential tool for reducing conflict intensity by raising the opportunity cost of being an insurgent and improving the willingness of civilians to support the government. ${ }^{1}$ At the same time, however, such programs may increase violence, for example if the resources flowing into conflict areas make territorial control of these locations more attractive for insurgents. ${ }^{2}$

What effect government programs have on internal conflict intensity is therefore an empirical question. Across a number of different countries and types of programs, recent papers find both positive and negative impacts of government programs on internal conflicts that are typically consistent with more than one explanation. ${ }^{3}$ Given this heterogeneity, a deeper understanding of how government programs of different types and across different contexts affect internal violence is of high policy relevance.

In this paper, we analyze the impact of the world's largest public-works pro-

\footnotetext{
${ }^{1}$ See e.g. Grossman (1991) for an opportunity cost model and Berman, Shapiro and Felter (2011) for a model of civilian support in the context of street gangs.

${ }^{2}$ See e.g. Hirshleifer (1989), Grossman (1991), Skaperdas (1992).

${ }^{3}$ See e.g. Berman, Shapiro and Felter 2011, Berman et al. 2011, Nunn and Qian 2012, Crost, Felter and Johnston 2012, Dube and Vargas 2013
} 
gram, the Indian National Rural Employment Guarantee Scheme (NREGS), on the incidence of Maoist violence in the country, which the Indian Prime Minister referred to as the "single biggest internal security threat". ${ }^{4}$ NREGS is based on a legal guarantee of 100 days of public-sector employment to all rural households (about 70 percent of the population) willing to work at the minimum wage, and annual expenditures on the scheme amount to around one percent of Indian GDP. While the program's main goal is to generate labor market opportunities, one of the expectations of the government was to reduce incidents of Maoist-related violence.

Based on the existing literature, it is unclear how NREGS should be expected to affect insurgency-related violence. NREGS operates on a much larger scale than the programs analyzed in the existing within-country analyses, and large implementation problems especially in the initial stages seem to have severely limited the monetary benefits for the poor. Furthermore, as a publicworks program, the employment guarantee scheme is a different type of government intervention than the ones analyzed in the literature. These differences in context, delivery mechanism, and scale may have important consequences for the relevance of various mechanisms. ${ }^{5}$

Our empirical estimation strategy relies on the fact that NREGS was rolled out non-randomly in three implementation phases, with poor districts being treated earlier. The government used an algorithm to assign districts to phases which generates state-specific treatment discontinuities and allows the use of a regression-discontinuity design to analyze the empirical impact of the program.

\footnotetext{
${ }^{4}$ Hindustan Times, April 13 2006: Naxalism biggest threat: PM

${ }^{5}$ See e.g. Berman et al. (2013).
} 
The results show that treatment at the cutoff leads to about 914 more fatalities in about 368 additional incidents over the following year. We find that more attacks are initiated by the police, that insurgents are the most affected group, but that there is little impact on police casualties. There is also some evidence of an increase in the number of attacks by insurgents on civilians. The results are robust across different specifications and predominantly concentrated in the short run.

We discuss the empirical predictions of the most prominent theories in the existing literature. While a public-works program like NREGS may be seen as a combination of an employment intervention and an infrastructure program, the program in practice hardly seems to create any assets or destroyable infrastructure (Ministry of Rural Development 2010). This means that NREGS does not provide many appropriable assets and limits the opportunities for the insurgents to sabotage the scheme. While the public-works scheme also suffers from implementation problems, the actual and especially the expected future benefits from the scheme may therefore play the larger role in explaining the empirical patterns. ${ }^{6}$

Overall, our paper contributes to our understanding of the impact of government programs on insurgency-related violence in a number of ways. First, the empirical findings suggest that NREGS led to an increase in violence in the first year of implementation and especially the first few months. This means that dynamic patterns are important, which so far have been largely ignored in the literature. Second, the results are most consistent with a citizen-support

\footnotetext{
${ }^{6}$ See e.g. Dutta et al. (2012) and Niehaus and Sukhtankar (2013) for implementation issues with NREGS.
} 
explanation in which the introduction of NREGS makes civilians more likely to assist the state in the fight against insurgents, but we cannot fully rule out some alternative explanations like an increase in the spotlight on treatment districts. Third, while most of the existing literature focuses on programs that are implemented quite well, the Indian context provides the often more realistic case of a government initiative that at least initially faced severe implementation issues. Our results paired with other evidence from the literature suggest that the promise of development in the form of anticipated program benefits may already have important consequences for conflict intensity. Fourth, in contrast to most of the existing literature that focuses on infrastructure programs and food-aid schemes, NREGS is mainly a job-creation program. Based on our results, the impacts of a public-works program on violence are more similar to infrastructure programs (Crost, Felter and Johnston 2014) and food-aid schemes (Nunn and Qian 2012) than US-implemented reconstruction programs (Berman, Shapiro and Felter 2011) at least in the short run, albeit for plausibly different reasons. Fifth, the program in question is much larger in scale than the other studied programs and the conflict has been the major internal security threat for one of the world's largest countries since the late 1960s.

The remainder of this paper is structured as follows: Section 2 discusses potential hypotheses regarding the impact of NREGS on violence. Section 3 provides some background on the Maoist movement and NREGS, whereas section 4 describes the empirical strategy and the data. Section 5 presents the main results as well as some extensions and robustness checks, and section 6 
concludes.

\section{Theories about the Impact of Government Programs on Violence}

There are a number of existing theories in the broader literature on the relationship between development and conflict that are relevant for the impact of government programs on violence. Two prevalent theories in the literature predict a fall in conflict intensity. The first theory is an opportunity-cost story: If the program provides jobs and other welfare benefits, it will increase the opportunity cost of being a Maoist. This should make retention and recruitment of rebels more difficult and decrease their ability to inflict violence (see e.g. Grossman 1991 for such a model). ${ }^{7}$

The second theory that predicts a fall in violence after the introduction of NREGS is a citizen-support or 'hearts and minds' explanation. The introduction of a government program like NREGS may improve the relationship of the state and its citizens by making the government's commitment to economic development more credible. This may make civilians more willing to share information with the police, which improves police effectiveness in tracking down insurgents, and leads to a decrease in violence as the insurgents lose the fight (see e.g. Berman, Shapiro and Felter 2011 for a model on counterinsurgency in Iraq and the Akerlof and Yellen 1994 study on street-gangs).

\footnotetext{
${ }^{7}$ This idea is also closely related to work on economic inequality and group formation in the conflict literature. See e.g. Grossman (1999), Fearon (2007).
} 
In contrast to these two theories, the idea of competition for resources suggests an increase in violence after the introduction of NREGS due to a larger resource pie that is worth fighting over (see e.g. Hirshleifer 1989, Grossman 1991, Skaperdas 1992): Contest models that focus on this channel usually predict that when resources rise in a region in equilibrium more effort will be put into fighting than into production. Again, this presupposes that NREGS generates appropriable resources. We would also expect both rebel attacks against police forces and police-initiated attacks against the insurgents to increase over time as more assets are created, but there is little reason to expect an increase in violence against civilians.

A second potential mechanism for a violence increase is another version of the citizen-support channel, which is based on the idea that increased citizen support may well lead to an initial increase in violence through more police attacks and potential retaliatory attacks by insurgents on civilians before violence decreases in the longer run. In the appendix, we develop a model of citizen support that takes into account potential dynamic patterns. It sets up a two-stage game between the government, the insurgents and the civilians. Unlike similar models in the literature (Berman, Shapiro and Felter 2011), insurgents try to acquire territorial control, and can affect the probability of control by increasing the number of attacks against the police. Civilians choose how much information to share with the police, whereas the police and rebels choose the amount of military action to take. In equilibrium, the model predicts that the introduction of a government program will lead to an increase in the support provided by civilians to the police. This leads to a violence 
increase, which is driven by police-initiated attacks and retaliatory attacks by the insurgents against civilians. Violence levels are high in the short run, but should fall over time as the government starts winning the conflict due to better information.

Another mechanism that predicts an increase in violence is that NREGS may put a spotlight on treatment areas, encouraging the police to increase their crime reduction efforts there. As NREGS is a big program that has garnered a lot of media attention, this could incentivize state and district leaders to put pressure on the police to work harder to ensure a good image of their districts in the press, for example. This increased police effort implies the same pattern as the citizen-support channel, with an increase in violence and especially of police-initiated attacks. The spotlight theory should encourage the police to crack down on other forms of crime as well to make the security situation in their district look good, however. Moreover, there is no retaliation motive against civilians in this case.

While most of these different theories can be disentangled by focusing on the implied patterns of changes in violence and of the most heavily affected groups, available qualitative and quantitative evidence on the nature of the employment guarantee scheme and the Maoist conflict also provides useful information on the attractiveness of the various mechanisms in the Indian context. 


\section{Background}

\subsection{The Naxalite Movement}

According to the Government of India, the Naxalite movement is one of India's most severe threats to national security. In 2006, Prime Minister Manmohan Singh famously referred to it as "the single biggest internal security challenge ever faced by our country". ${ }^{8}$ Members of the movement are typically called Naxalites or Maoists.

Naxalites have been operating since 1967, but violence exacerbated after the two biggest previously competing Naxalite groups joined hands to form the Communist Party of India (Maoist) in 2004 (Lalwani 2011). The Indian Home Ministry believed the movement to have around 15000 members in 2006, and to be active in 160 districts (Ministry of Home Affairs 2006). Figure 1 shows all the districts that experienced at least one Maoist incident between January 2005 and March 2008, the period studied in this paper, in black, dark grey and light grey. As can be seen, Naxalite-affected districts are concentrated in the eastern parts of India. These areas are often referred to as the Red Corridor.

The Naxalites' main goal is to overthrow the Indian state and to create a liberated zone in central India, since they believe that the Indian government neglects the lower classes of society and exclusively caters to the elites. Decades of using military force have been largely unsuccessful in suppressing the movement. A number of researchers note that India traditionally relies almost exclusively on military strength to fight the Naxalites (see e.g.

\footnotetext{
${ }^{8}$ Hindustan Times, April 13, 2006: Naxalism biggest threat: PM
} 
Banerjee and Saha 2010, Lalwani 2011). Many observers also refer to the often widespread disregard for local perceptions as well as the sometimes excessively brutal nature of police force behavior that affects many civilians (Bakshi 2009, Lalwani 2011, Sundar 2011).

Both Maoists and security forces believe that civilians have a lot of information on the insurgents, so pressures on the local tribal population (called adivasis) to pick a side and cooperate with one of the conflict parties are high. The Naxalites' continued survival depends on help from civilians who hide them and provide them with resources and information. Maoist insurgents often warn the local population not to provide shelter or information to police forces, for example, and instead ask them to keep track of government personnel and their actions. Adivasis also face economic incentives to join the conflict: Many areas face chronic underdevelopment, and since their knowledge of local conditions in the often remote forest areas is very valuable, working for one of the conflict parties allows the poor to earn some income (Mukherji 2012).

In consequence, many adivasis are involved in the conflict as tacit supporters, informants and recruited fighters on both sides, and switching sides once conditions change is not uncommon. ${ }^{9}$ Vanden Eynde (2011) also shows that Naxalite violence against civilians increases after negative rainfall shocks, which is consistent with his theoretical model in which Maoists try to prevent the local population from being recruited as government informants during bad economic times. A number of instances where Maoists left leaflets after

${ }^{9}$ See e.g. Mukherji (2012) 
killing civilians, accusing them of being police informers, are also in line with the idea that Maoists retaliate against civilians. ${ }^{10}$

In light of this complex situation, the view that military force alone is not effective in solving the Naxalite problem in the long run seems to have grown in recent years. The central government has shown a growing interest in increasing economic development in underdeveloped areas through anti-poverty programs, in the hope that an improvement in the local population's situation would lead to a reduction in Naxalite violence (Ramana 2011). NREGS is by far the most ambitious and largest anti-poverty program introduced by the Indian government.

Conflict intensity seems to have decreased in recent years. The Maoists have been forced to move out of many traditional areas of their control (Mukherji 2012). Improved access to information seems to have played an important role in this development: The Indian Home Secretary Gopal K. Pillai said in 2010, for example, that the intelligence gathering system of the police has improved over the last couple of years, making police forces more successful at catching Maoists. ${ }^{11}$ These developments are also recognized by the insurgents, who are accusing the government of turning the local population into police informers and of using surrendered Maoists as sources of information. ${ }^{12}$

\footnotetext{
${ }^{10}$ See appendix for some examples and details about the connection between the Maoist conflict and politics.

${ }^{11}$ Summary of a lecture given by Gopal K. Pillai on March 10, 2010: http://www.idsa.in/event/EPLS/Left-WingExtremisminIndia

${ }^{12}$ See appendix for details.
} 


\section{$3.2 \quad$ NREGS}

The National Rural Employment Guarantee Scheme (NREGS) is often referred to as the largest government anti-poverty program in the world. The scheme provides an employment guarantee of 100 days of manual public-sector work per year at the minimum wage to all rural households. The legal right to this employment is laid down in the National Rural Employment Guarantee Act (NREGA) that was passed in the Indian Parliament in August 2005. All households can apply for work at any time of the year as long as they live in rural areas and their members are prepared to do manual work at the minimum wage. $^{13}$

NREGS was rolled out non-randomly in accordance with a poverty ranking across the country in three phases: 200 districts received the scheme in February 2006 (Phase 1), whereas 130 districts started implementation in April 2007 (Phase 2). Since April 2008, the scheme operates in all rural districts in India (Ministry of Rural Development 2010).

Many of the poorest Indian districts are also those heavily affected by Naxalite violence, as can be seen from Figure 1. The figure shows Maoistaffected districts predicted to receive NREGS in Phase 1, Phase 2, and Phase 3 in black, dark grey, and light grey, respectively. A large proportion of Maoistaffected districts are poor enough to be assigned to the first implementation phase.

An emerging literature suggests that implementation issues may substan-

\footnotetext{
${ }^{13}$ For more details on the scheme see e.g. Dey et al. (2006), Government of India (2009), and Ministry of Rural Development (2010).
} 
tially limit the effectiveness of the program, with widespread rationing of NREGS employment especially in poorer states and corruption in the form of underpaid wages and ghost workers (Dutta et al. 2012, Niehaus and Sukhtankar 2013). A number of papers also analyze the impact of the employment guarantee scheme on rural Indian labor markets. Using difference-in-difference approaches, empirical analyses often suggest low overall benefits but positive impacts on public employment and private-sector wages in the agricultural offseason, in areas with high implementation quality, and among casual workers (Azam 2012, Berg et al. 2012, Imbert and Papp Forthcoming). Zimmermann (2013a) uses a regression-discontinuity framework and finds that NREGS is primarily used as a safety net rather than as an additional form of employment and does not lead to an overall increase in public-sector employment, the casual private-sector wage or household income. Taken together, the empirical literature on NREGS therefore suggests that while there may be important heterogeneous impacts, overall NREGS does not raise the opportunity cost of other occupations in the traditional sense of offering a better paid job, although the program may affect opportunity costs through occupational changes induced by the safety net (Zimmermann 2013a).

The available information on the implementation of NREGS also helps rule out that the competition for appropriable resources explains the program effects on violence, since NREGS creates hardly any appropriable assets. A breakdown of project categories reveals that NREGS focuses on droughtproofing measures and does not generate a lot of infrastructure improvement 
or physically appropriable assets. ${ }^{14}$

Since we focus on a similar time interval as the existing literature, the impacts of the scheme on violence in this paper are therefore unlikely to be driven by any substantial household income increases or by a fight for the control of appropriable resources. Instead, the effects could be due to changes in the opportunity cost of being a Maoist supporter or the promise of government benefits if households expect future benefits from NREGS or see it as a signal of the government's commitment to the fight against poverty. NREGS differs from previous, mostly unsuccessful anti-poverty programs because of its legal status, scope, and prominence in the government's agenda, which may have made the promise of development more credible. Zimmermann (2013b) finds effects of NREGS on general election outcomes that are consistent with such a view: districts that had just started implementing NREGS in the year prior to the election were more likely to vote for the government and seemed less sensitive to implementation quality than areas with longer access to the program.

Two concurrent papers in the literature analyze the impact of NREGS on Maoist violence and discuss potential explanations for their results. ${ }^{15}$ Fetzer (2013) shows that NREGS attenuates the relationship between rainfall shocks and Maoist violence, which could mean that the importance of income fluctu-

\footnotetext{
${ }^{14}$ According to Ministry of Rural Development (2010), the breakdown of projects for the financial year 2008-09, was: $46 \%$ water conservation, $20 \%$ provision of irrigation facility to land owned by lower-caste individuals, $18 \%$ land development, $15 \%$ rural connectivity (roads), $1 \%$ any other activity.

${ }^{15}$ In a policymaker-oriented extension of this paper, we show that our results are also robust to using a simple difference-in-difference strategy and provide some descriptive evidence of dynamic patterns of Maoists arrests and surrenders (Khanna and Zimmermann 2014).
} 
ations as a driver of Maoist violence declines once NREGS provides a safety net during bad economic times. Dasgupta, Gawande and Kapur (2014) use a difference-in-difference approach and find that NREGS increases Maoist violence in the first year of implementation, but then leads to lower violence in the year after. This long-run reduction in violence is concentrated in Andhra Pradesh, a state with high implementation quality relative to other areas. The authors attribute this effect to rising opportunity costs. ${ }^{16}$

While the opportunity-cost channel is consistent with these results, the mechanism cannot explain the overall effect of the employment guarantee scheme that we find in this paper. Additionally, the results in both papers could also be consistent with other explanations such as a citizen-support story. Vanden Eynde (2011) argues, for example, that the link between violence and rainfall shocks arises out of the citizen-support channel since he proposes a model where Maoists try to prevent the local population from becoming police informants in bad economic times by increasing their attacks on civilians suspected to work for the government. Fetzer's (2013) results could therefore also be consistent with the citizen-support channel, since NREGS increases the willingness of civilians to help the government at all times, and not just during bad economic times, breaking the link between rainfall fluctuations and violence. The empirical patterns in Dasgupta, Gawande and Kapur (2014) are also consistent with a citizen-support channel explanation which predicts a short-run increase and a long-run decrease in violence, whereas the higher conflict intensity in the short run is difficult to explain with an opportunity-

\footnotetext{
${ }^{16}$ We are unable to look at the longer-run impacts of NREGS because this requires comparing Phase 1 to Phase 3 districts, violating RD assumptions.
} 
cost story.

In terms of the potential mechanisms discussed in the theory section, qualitative and quantitative evidence on the working of NREGS therefore points to a number of theories as potentially relevant in the Indian context, including opportunity cost, citizen support and spotlight theories. To test these different explanations empirically, we exploit the roll-out of the program in a regression-discontinuity design.

\section{Identification Strategy, Data and Empirical Specification}

\subsection{NREGS Roll-out and the Assignment Algorithm}

The Indian government used an algorithm to determine which districts would start implementing the program in which phase. Zimmermann (2013a) reconstructs the algorithm from information on the NREGS roll-out and institutional knowledge about the implementation of development programs in India. The algorithm has two stages: First, the number of treatment districts that are allocated to a given state in a given phase is determined. It is proportional to the prevalence of poverty across states, which ensures inter-state fairness in program assignment. Second, the specific treatment districts within a state are chosen based on a development ranking, starting with the poorest districts.

We use this procedure in our empirical analysis. The 'prevalence of poverty' 
measure is the state headcount ratio times the rural state population, which provides an estimate of the number of below-the-poverty-line people per state. A state is assigned the percentage of treatment districts that is equal to the percentage of India's poor in that state. For the calculations, we use headcount ratios calculated from 1993-1994 nationally representative National Sample Survey (NSS) data. ${ }^{17}$

The development index used to rank districts within states comes from a Planning Commission report from 2003 that created an index of economic underdevelopment. The index was created from three outcomes for 17 major states: agricultural wages, agricultural productivity, and the district proportion of low-caste individuals (Scheduled Castes and Scheduled Tribes) (Planning Commission 2003). ${ }^{18}$ Districts were ranked on their index values. In addition to the algorithm, the government had a separate list of 32 districts heavily affected by Maoist violence. ${ }^{19}$ These districts were not subject to the algorithm and all received NREGS in the first implementation phase. In order to closely replicate the algorithm used, we drop these districts from our sample. Our results are robust to including them and assigning them a predicted treatment status based on their economic development index values.

The two-step algorithm results in state-specific treatment cutoffs. Since

\footnotetext{
${ }^{17}$ We use the state headcount ratios from Planning Commission (2009), since the original headcount ratio calculations do not have estimates for new states that had been created since then. As official Planning Commission estimates, they are likely to be closest to the information the Indian government would have had access to at the time of NREGS implementation.

${ }^{18}$ Data on the outcome variables was unavailable for the remaining Indian states, and it is unclear whether a comparable algorithm using different outcome variables was used for them. We therefore restrict our empirical analysis to these 17 states. There are no Maoist-related incidents in NREGS districts in the dropped states in our sample period.

${ }^{19}$ See e.g. Planning Commission (2005).
} 
implementation proceeded in three phases, two cutoffs can be empirically identified: the cutoff between Phase 1 and Phase 2, and the cutoff between Phase 2 and Phase 3. These correspond to the Phase 1 and Phase 2 NREGS roll-out, respectively. We exploit both cutoffs in a regression discontinuity framework.

Ranks are made phase- and state-specific and are normalized so that a district with a normalized state-specific rank of zero is the last program-eligible district in a state in a given phase. ${ }^{20}$ This allows the easy pooling of data across states.

The overall prediction success rate of the assignment algorithm is 83 percent in Phase 1 and 82 percent in Phase 2. It is calculated as the percent of districts for which predicted and actual treatment status coincide. ${ }^{21}$ This means that there is some slippage in treatment assignment in both phases, and considerable heterogeneity in the performance of the algorithm across states. Nevertheless, the algorithm performs quite well in almost all states and the prediction success rates are also considerably higher than the ones that would be expected from a random assignment of districts, which are 40.27 percent for Phase 1 and 37.45 percent for Phase 2, respectively. ${ }^{22}$ Overall, this suggests that the proposed algorithm works well for predicting Phase 1 and Phase 2 district allocations.

The RD framework crucially relies on the assumption that beneficiaries

\footnotetext{
${ }^{20}$ Rank data in the 17 major states is complete for all rural districts. Rank data is available for 447 of 618 districts. Data for the index creation was unavailable in some states, in most cases because of internal stability issues during the early 1990s when most of the data was collected. We exclude these states from the analysis.

${ }^{21}$ Prediction success rates for Phase 2 are calculated after dropping Phase 1 districts.

${ }^{22}$ Part of the fuzziness of the treatment discontinuity is potentially due to measurement error in the headcount ratios if the Indian government used different values than the ones reported in Planning Commission (2009).
} 
were unable to perfectly manipulate their treatment status, so that observations close to the treatment cutoff differ only with respect to their treatment status (Lee 2008). In the case of the two-step RD, this means that districts should not have been able to manipulate the algorithm in either step. This seems plausible: The headcount poverty ratio used data from the mid-1990s, which had long been available by the time the NREGS assignment was made. The economic underdevelopment index was also constructed from outcome variables collected in the early 1990s, eliminating the opportunity for districts to strategically misreport information. Additionally, the suggestion of the original Planning Commission report was to target the 150 least developed districts, but NREGS cutoffs were higher than this even in Phase 1 (200 districts in Phase 1). Lastly, the Planning Commission report lists the raw data as well as the exact method by which the development index was created. ${ }^{23}$

Figures $2 \mathrm{a}$ and $2 \mathrm{~b}$ look more closely at the distribution of index values over state-specific ranks. They plot the relationship between the Planning Commission's index and the normalized state-specific ranks for the Phase 1 and Phase 2 cutoffs, respectively. For most states, the poverty index values seem smooth at the cutoff of 0, again suggesting that manipulation is not a big concern.

Another way of analyzing whether manipulation is likely to be a problem is to test whether there are any discontinuities at the cutoffs in the baseline data. Table 2 presents the results of such an analysis for the main outcome variables

\footnotetext{
${ }^{23}$ This does not mean that actual treatment assignment was not subject to political pressures. It can be shown that deviations from the algorithm are correlated with party affiliation.
} 
used in this paper for the time period before NREGS was rolled out to any phase. ${ }^{24}$ Figures 3 and A.7 show the results graphically. Overall, these tables and figures suggest again that manipulation is not an important problem. ${ }^{25}$

Finally, we need to verify that there really is a discontinuity in the probability of receiving NREGS at the state-specific cutoff values. Figures 2c and $2 \mathrm{~d}$ show the probability of receiving NREGS in a given phase for each bin, as well as fitted quadratic regression curves and corresponding 95 percent confidence intervals on either side of the cutoff. The graphs demonstrate that the average probability of receiving NREGS jumps down about 40 percentage points at the discontinuity in both phases. This suggests that there is indeed a discontinuity in the treatment probability at the cutoff.

\subsection{Data and Variable Creation}

The primary source of data used in this paper comes from the South Asian Terrorism Portal (SATP). The SATP aggregates and summarizes news reports on Naxalite-related incidents, and such summaries usually contain the location of the incident (district), the date of the incident, the number of casualties (Naxalites, civilians, or police), and the number of injuries, abductions or surrenders. The source also codes the incident as 'minor' or 'major.'

In many cases, the party initiating an incident can be identified from the newspaper description, and we manually code up these details for the incidents in our sample. Events are labelled as police-initiated, Maoist initiated against

\footnotetext{
${ }^{24}$ Appendix Table A.7 presents it for employment, wages and education.

${ }^{25}$ Our main results also include the baseline outcome variable as a regressor, which controls for any baseline differences and should soak up some of the residual variance.
} 
the government or Maoist incidents against civilians. ${ }^{26}$ Using this information we construct violence-intensity variables at the district-month level, with 'no incidents' being coded as zero. If some information is unclear, we verify the information by searching for the source news reports. We use data between January 2005 (the earliest time for which data is available on the website) and March 2008, since the districts in the final phase started receiving NREGS in April 2008. This gives us data before and after implementation of the program, with about two years of post-treatment data for Phase 1 districts and a year's worth of after-NREGS data for Phase 2 districts. This dataset is then merged with information on the poverty rank from the 2003 Planning Commission Report.

Table 1 shows some summary statistics for our primary variables of interest. Our dataset records 1458 incidents, covering a total of 2030 fatalities. 267 of these incidents were coded by the SATP source as 'major'. Furthermore, in this 39-month period, 2545 people were either injured, abducted or surrendered to the police. On average, in any given red-corridor district, there are about 0.44 deaths a month related to Naxalite activities and about 0.32 incidents a month.

We also collect data on the police force from the Indian Ministry of Home Affairs, which contains state-level information on the number of police officers, police posts and stations, as well as some other measures of police strength. District-level data on other types of crimes also come from the Ministry of Home Affairs.

\footnotetext{
${ }^{26}$ See the appendix for more information about the dataset and coding examples.
} 


\subsection{Empirical Specification}

The state-specific district ranks of the algorithm can be used as a running variable in an $\mathrm{RD}$ framework. ${ }^{27}$ Ideally, we would restrict the data to observations in the close neighborhood of the cutoff and estimate the treatment effect using local linear regressions. As the number of observations near the cutoff is limited, however, we are using all available relevant observations: We drop Phase 3 districts in our analysis of the first phase of NREGS, and drop Phase 1 when analyzing the Phase 2 cutoff. Such a larger bandwidth will improve the precision of the estimates due to an increased sample size, but potentially introduces bias since observations far away from the cutoff can influence the estimates (Lee and Lemieux 2010).

We address this concern in three ways: First, all result tables show the estimated coefficients for three different parametric specifications (linear, linear with slope of regression line allowed to differ on both sides of the cutoff, quadratic). The quadratic flexible specification is always outperformed statistically by the linear flexible specification, and using F-tests we cannot reject the null hypothesis that other higher-order polynomial terms are irrelevant. ${ }^{28}$ Second, while our results use all districts of the treatment and control phase in a given specification, we test the robustness of our main estimates by varying the bandwidth and restricting the sample to observations closer to the cutoff. Third, Figures 4a to 4f show the non-parametric relationships between the

\footnotetext{
${ }^{27}$ Our results are also robust to using the poverty index values as the running variable.

${ }^{28}$ More flexible models also tend to be unstable in the second stage of the two-stage least squares estimation, although the coefficients are often qualitatively similar to the quadratic results. Gelman and Imbens (2014) discourage the use of higher-order polynomials.
} 
main outcome variables and also plot quadratic polynomial regression curves. Similar to the summary statistics, they show that insurgency-related violence intensity is low in many districts. We therefore also test the robustness of our results to using a zero-inflated Poisson model.

Due to the fuzzy RD, we use a two-stage least squares specification where actual NREGS receipt is instrumented with predicted NREGS treatment according to our algorithm, although intent-to-treat effects are reported in the appendix. To increase the precision of our estimates, we control for the baseline outcome variable. ${ }^{29}$ We run results separately by cutoff. Most of our empirical analysis focuses on the Phase 1 cutoff, since baseline Maoist violence levels in districts near the Phase 2 cutoff are much lower. The bulk of the effect of NREGS on violence should therefore occur in early treatment districts.

We run the regression equation below where $f($.$) is a function of actual$ NREGS receipt nregs (instrumented with predicted NREGS receipt) and the district's rank based on the state-specific normalized index rank. We show results for linear, linear with flexible slopes and quadratic functions of $f($.$) .$

$$
y_{i j}=\beta_{0}+\beta_{1} \text { nregs }_{i}+f(\text { rank, nregs })+\beta_{2} \text { baseline } y_{i}+\epsilon_{i j}
$$

$y_{i j}$ is an outcome variable in district $i$ and month $j$, and the coefficient of interest is $\beta_{1}$. Standard errors are clustered at the district level.

\footnotetext{
${ }^{29}$ The results are robust to controlling for month and year fixed effects, or month*year fixed effects.
} 


\section{Results}

\subsection{Main Results}

The main results are presented in Tables 3 to 5 . Table 3 shows the impact of NREGS on Maoist incidents for the four main outcome variables in the first year after the program was introduced: individuals affected (deaths/ injuries/ abductions); deaths; major incidents; and total incidents. Panel B normalizes the variables by the 2001 Census population counts, showing the results per10 million people. Each panel has three different specifications: linear, linear with a flexible slope, and quadratic. ${ }^{30}$

Panel A of Table 3 shows that violence increases in Phase 1 districts after NREGS is introduced. Depending on the specification, there is a rise of about 0.55 to 0.75 deaths per month in a given district. At a mean of about 0.44 deaths per month in a Red Corridor district, this amounts to about a $125 \%$ increase from the baseline level. Similarly, the number of affected persons increases by about 0.56 to 0.73 units per district-month, which amounts to a rise of $56 \%$. The number of total incidents rises by about 0.22 to 0.27 incidents per month, or about $70 \%$. These results are robust across the different parametric specifications. A crude calculation suggests that these effects translate into between 785 and 1071 more fatalities in about 314 to 385 more incidents in the year after implementation. This overall increase in violence is not consistent with the opportunity cost channel or the traditional 'hearts and minds' approach, both of which predict a fall in violence. Instead, the results support

\footnotetext{
${ }^{30}$ Specifications control for (estimated) police force changes, but the results are robust to excluding these controls. They are presented in Panel B of Table A.13.
} 
explanations that predict a violence increase. Panel B shows similar impacts once we normalize the variables by population.

Figures 4a to $4 \mathrm{f}$ use quadratic polynomials and the optimal quantile-spaced binning procedure suggested by Calonico et al. (Forthcoming) to plot the primary variables against the rank variable, and show a significant discontinuity at the cutoff for all the variables of interest. Figure 5 plots the monthly RD coefficients for the number of incidents, where the first vertical line depicts the time when the employment guarantee act was passed, and the second vertical line marks when Phase 1 was implemented. The figure shows that, across the different specifications, the increase in violence is almost immediate after NREGS introduction. Similarly, Figure 6, which plots the monthly $\mathrm{RD}$ coefficients for the number of persons affected, shows that while there is an immediate increase in violence, there is also a slight dissipation of effects over time. The figures therefore suggest that violence increases almost immediately after program introduction rather than slowly over time. This pattern, together with existing qualitative and quantitative evidence on low implementation quality, types of projects, and locations of insurgent attacks in our data makes the competition for resources and sabotage explanations less plausible, since violence should increase more strongly over time once assets can be appropriated or more projects can be sabotaged.

The data allows us to distinguish between civilians, Maoists and the police force. In many cases, it is also possible to code up which conflict party initiated the attack. All of this information allows us to better distinguish predictions of various hypotheses: According to the citizen-support channel, for example, the 
police should have better information to catch Naxalites, and the insurgents, in turn, may want to retaliate against civilians for helping the police. Thus, we should see an increased number of police-initiated attacks against insurgents and more attacks by Maoists on civilians. This also implies that the bulk of the impact should be concentrated on Naxals and civilians. Table 4 reports the empirical results of this analysis, focusing again on Phase 1 districts.

Panel A of Table 4 shows that an important part of the increase in violence comes from police-initiated attacks on the Maoists. This is consistent across specifications. The results also show the Maoists retaliating against civilians, but not a very large increase in Maoist-on-police attacks. The retaliation against civilians is consistent with the citizen-support story, but there is no reason to expect retaliation against civilians under the spotlight and competition for resources or sabotage explanations. Additionally, the competition for resources story implies a large increase in the number of Maoist attacks on the police, which is not what we find.

Panel B of Table 4 presents the RD results for fatalities by group. Civilian and police casualty estimates are small and imprecisely estimated, whereas Naxal casualties increase by between 0.3 and 0.4 deaths a month after the introduction of the NREGS, an effect that is also statistically significant at the 5\% level. Appendix Table A.11 presents the per-capita results, which again show that the Maoist deaths contribute to most of the new casualties. The police force does not experience a statistically significant increase in fatalities, and the magnitudes are also much smaller. Overall, these results are again consistent with the citizen-support predictions, but much less so with 
alternative theories.

Focusing on the dynamic patterns of Phase 1, Table 5 divides the posttreatment period into the short run (Panel A) and the medium run (Panel B). There are 14 months before Phase 2 receives NREGS, so we divide them equally into the short run (first 7 months after NREGS eligibility) and the medium run (months 8 through 14). The results show that an important part of the impact occurs in the short run. The impact on the number of affected persons is somewhere between 1.6 and 2.2 times higher, and fatalities are 1.4 to 1.6 times higher in the short run than in the medium run. These empirical patterns are consistent with the citizen-support channel and the spotlight theory, but not with the opportunity cost story or the resource-curse story, although rising opportunity costs over time once NREGS is implemented better could contribute to the downward trend in violence.

\subsection{Extensions}

The main results suggest that a citizen-support story and a spotlight theory fit the empirical results best, although a spotlight theory would not necessarily predict the retaliation effect by Maoists against civilians. A further test of the

plausibility of some versions of the spotlight theory is presented in Appendix Table A.8, which focuses on the impact of NREGS on other types of violence and crime. If police officers feel an increased pressure to perform better in treatment areas because of increased attention paid to NREGS districts, then we may expect that this should also apply to other crimes. Appendix Table A.8 provides no evidence of NREGS having a statistically significant impact 
on crime, however, and the magnitudes tend to be small. This reduces the plausibility of a spotlight explanation, although it cannot rule out all potential versions of it.

If the citizen-support channel is relevant, we should expect it to be especially important in areas where program awareness and implementation quality are higher, although this may also be consistent with more attention being paid to these areas in a spotlight theory approach. Therefore, the number of police-initiated attacks should be higher in these areas than in the rest of the country. One measure of implementation quality often used in the existing NREGS literature are the so-called 'star states' where, based on field reports, awareness of the program and implementation quality tend to be much higher than in the rest of the country (Dreze and Khera 2009, Khera 2011). In Table 6, the NREGS treatment variable is interacted with an indicator variable equal to one if a state is a 'star state', and zero otherwise. As the table shows, police-initiated attacks are indeed higher in star-state NREGS districts than in other treatment districts.

Given that violence levels increase almost immediately after the introduction of NREGS despite severe challenges with implementation in practice, an implication of this is that citizens may respond more strongly to the promise of development rather than actual program benefits. Zimmermann (2013b) finds results consistent with NREGS having such an effect at the time of the Indian general elections in 2009, where the districts with shortest exposure to the program were more likely to vote for the government and were less sensitive 
to implementation quality than areas with longer access to the program. ${ }^{31}$

If the promise of development is important, then we may find that civilians also change their behavior even in still untreated districts. This effect may occur especially in Phase 2 districts since the people in those districts can take Phase 1 implementation as a signal of the government's commitment to following through with the program and may be aware of their districts receiving the treatment soon. We would then expect to find positive spillover effects of the program onto Phase 2 districts.

Appendix Table A.9 confirms that this effect does indeed hold empirically. At the time that Phase 1 districts have access to NREGS (and other phases do not) there is an increase in violence in Phase 2 districts (Panel A). However, this increase dissipates over time, and by the time Phase 2 is in the spotlight, there is no longer any impact (Panel B). The Phase 2 results are therefore difficult to explain with the spotlight theory. If the police or media work harder in treatment areas due to increased attention on law and order in NREGS areas, there is no reason for the police or newspaper reporters in still untreated areas to increase their effort levels.

Overall, the empirical patterns presented in the results section suggest that violence increases when NREGS is introduced, and does so already in the very short run. A large proportion of the increase is due to police-initiated attacks on Maoists. There is also some retaliation by the Maoists on civilians, but most of the increase in fatalities is explained by rebels dying. All of these empirical

\footnotetext{
${ }^{31} \mathrm{~A}$ number of researchers believe that NREGS was important in ensuring the re-election of the Indian government (see Zimmermann 2013b for details). Electoral benefits from government programs have also been found in other contexts (see e.g. De la O 2013 and Manacorda et al. 2011).
} 
patterns are consistent with the predictions of a citizen-support model in which civilians are willing to share information and other forms of support with the police after NREGS implementation starts, which allows government troops to crack down more efficiently on the Maoists. They are difficult to explain with many alternative explanations, however, although we cannot completely rule out that there is an alternative explanation that fits the results.

\subsection{Robustness Checks}

In order to ensure that a handful of large attacks by Maoists or police are not driving the results, the we repeat the analysis by dropping all district-months wherein more than twenty persons were killed or injured. ${ }^{32}$ The results of this analysis are shown in Appendix Table A.10 and Figure A.8.

Another important concern is that there may be measurement error in the rank variable that is used as the running variable, which may lead to districts right at the cutoff being assigned to the wrong side of the cutoff. We provide a robustness check by using a donut-hole approach that drops the districts with state-level ranks lying between -1 and 1 (the cutoff is at a state-specific rank of 0). These results are presented in Panel A of Appendix Table A.12. They are similar, both in magnitude and statistical significance, to our main results, implying that the estimated treatment effects do not seem to be driven by measurement error of the observations close to the cutoff. Panel B of Table A.12 presents the main results when varying the bandwidth by restricting the analysis to observations closer to the cutoff, and once again produces similar

\footnotetext{
${ }^{32}$ This drops the most violent eleven district-months from the districts that received NREGS. The results are robust to picking other cutoffs.
} 
results.

Our main results are also robust to a number of other specifications presented in the appendix: Panel A of Table A.13 estimates the intent-to-treat (ITT) version of the main results, while Panel B of Table A.13 reproduces the main results without controlling for the strength of the police force. Both specifications consistently maintain the main results. ${ }^{33}$

Another potential concern with the main specifications is the nature of the data. All outcomes are count-data outcomes, but we estimate the treatment effects within a normal regression framework rather than using count-data models. Panel A of Appendix Table A.14 therefore presents the the results from a Zero-Inflated Poisson Count-Data Model. The Poisson model is the most widely used count-data model (Cameron and Trivedi 2013). Since the data has an excess of zero-values (i.e. no casualties in a given district-month), we use the zero-inflated version of this model. The coefficients are interpreted as the change in the log-counts of the dependent variable on introduction of NREGS, and again show the same qualitative patterns as our main results. The results are also robust to using other count data models like the hurdle model using a Logit-Poisson specification.

Panel B of Table A.14 presents the results using a difference-in-difference (DID) approach rather than the RD, which is the most common empirical iden-

\footnotetext{
${ }^{33}$ One possible simultaneous change with NREGS implementation is an increase in the size of the police force. Since we do not have data on the actual police force in a district, we estimate it using state-level information, where any change in the police force for a given state is assumed to be attributable to NREGS districts. In reality, these state-level estimates most likely overemphasize the change in the police force and may therefore provide us with conservative estimates of the impact of NREGS. Our main analysis therefore includes police force controls, although, as Panel B of Table A.13 shows, the results are very similar without these controls. Other tables are also robust to dropping police controls.
} 
tification strategy used to study the impacts of NREGS in the literature. We conduct two different types of DID exercises: the Intent-to-Treat (ITT) version, where treatment is assigned based on who should have received NREGS according to the algorithm; and the Actual Treatment version where treatment depends on actually receiving NREGS. While the DID approach estimates the overall average treatment effect on the treated and therefore a different parameter than the RD specifications, the results are again qualitatively similar.

Lastly, we conduct other robustness checks not reported here by re-doing our main results after controlling for rainfall shocks in the current month and in the entire preceding year. We also control for average monthly wages, and find that our results are robust to all these specifications. To the extent that rainfall shocks and wages capture what happens to income in these regions after NREGS is introduced, these results indicate that the opportunity-cost channel is not the driving force behind these results. In other specifications, we also control for the timing of the state elections, in some specifications using not just the election month but also up to 5-months leading up to an election, and our results are unaffected by these controls.

\section{Conclusion}

This paper has analyzed the impact of introducing a large public-works program in India, the National Rural Employment Guarantee Scheme (NREGS), on incidents of Maoist violence. We exploit the fact that the program was

phased in over time according to an algorithm that prioritized economically 
underdeveloped districts in a regression discontinuity $(\mathrm{RD})$ design. The results are robust across a number of different specifications and show a substantial rise in violence in the first year of implementation in the districts that received NREGS, especially in the very short run. Insurgents are the primary affected group as police-initiated attacks rise, with little impact on police force casualties. There is also some evidence for an increase in Maoist-initiated attacks against civilians. The impact is largest among districts that received NREGS in the first phase of the roll-out, but there are positive spillovers of violence to the districts that are next in line to receive the program.

These empirical patterns as well as other available qualitative and quantitative evidence on the conflict are consistent with a model in which the government program makes civilians more willing to support the police because it improves the relationship between the government and the people. In contrast, the results are difficult to explain with a number of alternative theories, although we cannot completely rule out that there is a different explanation that fits the results. Securing the assistance of the local population may therefore be an important factor in internal conflicts and may help answer Max Weber's (1919) question on whether the State should use force or development to tackle internal conflict. For the Indian government, which has been trying to fight the Naxalites for over 30 years, the best strategy may be to combine both force and development.

It is unclear, however, how successful such strategies are likely to be in the longer run. In the Indian context, a growing literature questions the effectiveness of NREGS as a tool for actual development due to various implementation 
problems, although the program still seems to provide some benefits through its safety net function. This implies that at least a part of what may win over the local community initially are anticipated welfare benefits and the promise of development rather than actual changes. Such a mere promise may not be credible enough to ensure the support received from the civilian population over time, however. Once civilians realize that the program is not delivering, this may not only stop civilian aid in exchange for the benefits of the program, but may lead to distrust in government programs in general. Therefore, an important component to winning continued civilian support may be to ensure that government anti-poverty programs are implemented effectively and actually fulfil the promise of development. 


\section{References}

Akerlof, George and Janet Yellen. 1994. 'Gang Behavior, Law Enforcement, and Community Values.' Issue 53 of CIAR Program in Economic Growth and Policy reprint series

Azam, Mehtabul. 2012. 'The Impact of Indian Job Guarantee Scheme on Labor Market Outcomes: Evidence from a Natural Experiment.' IZA Discussion Paper 6548.

Bakshi, G D. 2009. 'Left Wing Extremism in India: Context, Implications and Response Options.' Manekshaw Paper No. 9.

Banerjee, Kaustav and Partha Saha. 2010. 'The NREGA, the Maoists and the Developmental Woes of the Indian State.' Economic and Political Weekly, XLV(28): 42-48.

Berg, Erlend, Bhattacharyya, Sambit, Durgam, Rajasekhar, and Manjula Ramachandra. Can Rural Public Works Affect Agricultural Wages? Evidence from India. CSAE Working Paper WPS/2012-05, 2012.

Berman, Eli, Callen, Michael, Felter, Joseph H. and Jacob N. Shapiro. 2011. 'Do Working Men Rebel? Insurgency and Unemployment in Afghanistan, Iraq, and the Philippines.' Journal of Conflict Resolution 55 (4): 496-528.

Berman, Eli, Shapiro, Jacob N., and Joseph H. Felter. 2011. 'Can Hearts and Minds Be Bought? The Economics of Counterinsurgency in Iraq.' Journal of Political Economy, 119(4): 766-819.

Berman, Eli, Felter, Joseph H., Shapiro, Jacob N., and Erin Troland. 2013. 'Modest, Secure, and Informed: Successful Development in Conflict Zones.' American Economics Review Papers and Proceedings, 103(3): 1-8.

Borooah, Vani K. 2008. 'Deprivation, Violence and Conflict: An Analysis of 'Naxalite' Activity in the Districts of India. International Journal of Conflict and Violence, 2: 317-333.

Calonico, Sebastian, Cattaneo, Matias, and Rocio Titiunik. Forthcoming. 'Optimal Data-Driven Regression Discontinuity Plots.' Journal of the American Statistical Association.

Cameron, A. Colin and Pravin K. Trivedi. 2013. 'Regression Analysis of Count Data.' 2nd edition, Econometric Society Monograph No.53, Cambridge University Press. 
Crost, Benjamin, Felter, Joseph and Patrick Johnston. 2012. 'Conditional Cash Transfers and Civil Conflict: Experimental Evidence from the Philippines.' Mimeo

Crost, Benjamin, Felter, Joseph and Patrick Johnston. 2014. 'Aid under Fire: Development Projects and Civil Conflict.' American Economic Review, 104(6): 1833-56.

Dasgupta, Adi, Kishore Gawande, and Devesh Kapur. 2014. 'Can Antipoverty Programs Reduce Conflict? India's Rural Employment Guarantee and Maoist Insurgency,' Mimeo.

De la O, Ana. 2013. 'Do Conditional Cash Transfers Affect Electoral Behavior? Evidence from a Randomized Experiment in Mexico.' American Journal of Political Science, 57(1): 1-14.

Dey, Nikhil, Jean Dreze, and Reetika Khera. 2006. Employment Guarantee Act: A Primer. (Delhi: National Book Trust, India)

Dreze, Jean and Reetika Khera. 2009. 'The Battle for Employment Guarantee.' Frontline, 26(1).

Dube, Oeindrila and Juan F. Vargas. 2013. 'Commodity Price Shocks and Civil Conflict: Evidence from Colombia.' Review of Economic Studies, 80(4): 1384-1421.

Dutta, Puja, Murgai, Rinku, Ravallion, Martin, and Dominique van de Walle. 2012. 'Does India's Employment Guarantee Scheme Guarantee Enployment? World Bank Policy Research Working Paper 6003.

Fearon, James D. 2007. 'Economic development, insurgency, and civil war,' in Institutions and Economic Performance. Elhanen Helpman ed. Cambridge: Harvard University Press.

Fetzer, Thiemo. 2014. 'Can Workfare Programs Moderate Violence? Evidence from India,' Mimeo.

Gelman, Andrew and Guido Imbens. 2014. 'Why High-order Polynomials Should not be used in Regression Discontinuity Designs' NBER Working Paper 20405

Government of India. 2009. 'The National Rural Employment Guarantee Act.' 
Grossman, Herschell I. 1991. 'A General Equilibrium Model of Insurrections.' American Economic Review, 81(4): 912-21.

Grossman, Herschell I. 1999. 'Kleptocracy and revolutions.' Oxford Economic Papers, 51, 267-83.

Hirshleifer, Jack. 1989. 'Conflict and rent-seeking functions: Ratio versus difference models of relative success.' Public Choice, 63, 101-12.

Imbert, Clement, and John Papp. Forthcoming. 'Labor Market Effects of Social Programs: Evidence of India's Employment Guarantee.' American Economic Journal: Applied Economics.

Khanna, Gaurav and Laura Zimmermann. 2014. 'Fighting Maoist Violence with Promises ?Evidence from India? Employment Guarantee Scheme.' Economics of Peace and Security Journal, 9(1): 30-36.

Khera, Reetika. 2011. The Battle for Employment Guarantee. Oxford University Press.

Lalwani, Sameer. 2011. 'India's Approach to Counterinsurgency and the Naxalite Problem.' CTC Sentinel, 4(10): 5-9.

Lee, David S. 2008. 'Randomized Experiments from Non-Random Selection in U.S. House Elections.' Journal of Econometrics, 142(2): 675-697.

Lee, David S., and Thomas Lemieux. 2010. 'Regression Discontinuity Designs in Economics.' Journal of Economic Literature, 48(2): 281-355.

Manacorda, Marco, Edward Miguel, and Andrea Vigorito. 2011. 'Government Transfers and Political Support.' American Economic Journal: Applied Economics, 3(3).

Ministry of Home Affairs, Government of India. 2006. 'Annual Report 20062007.'

Ministry of Rural Development, Department of Rural Development, Government of India. 2010. 'Mahatma Gandhi National Rural Employment Guarantee Act 2005 - Report to the People 2nd Feb 2006 - 2nd Feb 2010.'

Mukherji, Nirmalangshu. 2012. The Maoists in India: Tribals under Siege. (London: Pluto Press, United Kingdom) 
Niehaus, Paul, and Sandip Sukhtankar. 2013. 'Corruption Dynamics: The Golden Goose Effect.' American Economic Journal: Economic Policy, 5(4): 230-269.

Nunn, Nathan and Nancy Qian. 2012. 'Aiding Conflict: The Impact of U.S. Food Aid on Civil War.' NBER Working Paper No. 17794.

oneworld.net. 2011. 'Community MGNREGS Programme for Naxalite Affected Areas.' Report.

Parashar, Swati. 2013. 'Armed Resistance, (In)Security and the Household: A Case Stuy of the Maoist Insurgency in India.' in The Global Political Economy of the Household in South Asia, edited by Juanita Elias and Samanthi J. Gunawardana, Palgrave Macmillan.

Planning Commission. 2003. 'Report of the Task Force: Identification of Districts for Wage and Self Employment Programmes.'

Planning Commission. 2005. 'Report of the Inter-Ministry Task Group on Redressing Growing Regional Imbalances.'

Planning Commission. 2009. 'Report of the Expert Group to Review the Methodology for Estimation of Poverty.'

Ramana, P.V. 2011. 'India's Maoist Insurgency: Evolution, Current Trends, and Responses.' in India's Contemporary Security Challenges, edited by Michael Kugelman, Woodrow Wilson International Center for Scholars Asia Program.

Skaperdas, Stergios. 1992. 'Cooperation, Conflict, and Power in the Absence of Property Rights.' American Economic Review, 82(4): 720-39.

Sundar, Nandini. 2011. 'At War with Oneself: Constructing Naxalism as India's Biggest Security Threat.' in India's Contemporary Security Challenges, edited by Michael Kugelman, Woodrow Wilson International Center for Scholars Asia Program.

Vanden Eynde, Oliver. 2011. 'Targets of Violence: Evidence from India's Naxalite Conflict.' Mimeo.

Weber, Max. 1919. 'Politics as a Vocation.' 'Politik als Beruf,' Gesammelte Politische Schriften, pp. 396-450. Duncker and Humblodt, Munich 
Zimmermann, Laura. 2013a. 'Why Guarantee Employment? Evidence from a Large Indian Public-Works Program.' Mimeo.

Zimmermann, Laura. 2013b. 'Jai Ho? The Impact of a Large Public Works Program on the Government's Election Performance in India.' Mimeo. 
Table 1: Summary Statistics

\begin{tabular}{l|ccc}
\hline & Mean & Mean & Total \\
\hline & Red Corridor Districts & All Districts & All Districts \\
Deaths & 0.441 & 0.116 & 2030 \\
Injured/Abducted/Captured & 0.553 & 0.146 & 2545 \\
Affected & 0.994 & 0.262 & 4575 \\
Major Incidents & 0.058 & 0.015 & 267 \\
Total Incidents & 0.317 & 0.084 & 1458 \\
\hline Maoists Killed & 0.162 & 0.043 & 744 \\
Civilians Killed & 0.166 & 0.044 & 763 \\
Police Killed & 0.114 & 0.030 & 523 \\
\hline
\end{tabular}

A unit of observation is a district in a given month and year (January 2005 - March 2008). "Red Corridor" districts are Maoist-affected districts. "Affected Persons" indicates number of persons killed, injured, abducted or captured. "Major Incidents" indicates number of Major Incidents as coded by the SATP website. "Total Incidents" is number of total Maoist-related incidents. 
Table 2: Baseline Pre-Treatment Results

\begin{tabular}{|c|c|c|c|c|}
\hline Specification & $\begin{array}{l}\text { Affected } \\
\text { Persons }\end{array}$ & Fatalities & $\begin{array}{c}\text { Major } \\
\text { Incidents }\end{array}$ & $\begin{array}{c}\text { Total } \\
\text { Incidents }\end{array}$ \\
\hline $\begin{array}{r}\text { Linear } \\
\text { R-squared }\end{array}$ & $\begin{array}{c}0.517 \\
(0.782) \\
0.005\end{array}$ & $\begin{array}{c}0.0666 \\
(0.317) \\
0.004\end{array}$ & $\begin{array}{c}0.0142 \\
(0.0319) \\
0.008\end{array}$ & $\begin{array}{c}-0.0232 \\
(0.110) \\
0.003\end{array}$ \\
\hline Linear Flexible Slope & $\begin{array}{c}0.0773 \\
(0.534) \\
0.004\end{array}$ & $\begin{array}{c}-0.147 \\
(0.277) \\
0\end{array}$ & $\begin{array}{c}-0.00850 \\
(0.0271) \\
0.001\end{array}$ & $\begin{array}{c}-0.0899 \\
(0.120) \\
0\end{array}$ \\
\hline $\begin{array}{l}\text { Quadratic } \\
\text { R-squared }\end{array}$ & $\begin{array}{c}0.198 \\
(0.758) \\
0.006\end{array}$ & $\begin{array}{c}-0.162 \\
(0.349) \\
0\end{array}$ & $\begin{array}{c}-0.0142 \\
(0.0345) \\
0.003\end{array}$ & $\begin{array}{c}-0.107 \\
(0.138) \\
0\end{array}$ \\
\hline Outcome Mean & 0.580 & 0.263 & 0.035 & 0.170 \\
\hline
\end{tabular}

Time period: 13 months pre-treatment.

Controls include baseline averages of each dependent variable and police force changes. Unit of observation is district-month. Regressions contain 2964 observations in 228 district-clusters (Phase 1 and Phase 2 districts) and 13 months. See Table 1 for additional notes. 
Table 3: Main Results

\begin{tabular}{|c|c|c|c|c|}
\hline & Panel A: & Non-Normalized & & \\
\hline Specification & $\begin{array}{l}\text { Affected } \\
\text { Persons }\end{array}$ & Fatalities & $\begin{array}{c}\text { Major } \\
\text { Incidents }\end{array}$ & $\begin{array}{c}\text { Total } \\
\text { Incidents }\end{array}$ \\
\hline Linear & $\begin{array}{c}0.636^{* *} \\
(0.294)\end{array}$ & $\begin{array}{c}0.594^{* *} \\
(0.275)\end{array}$ & $\begin{array}{c}0.104^{* * *} \\
(0.0402) \\
0.280\end{array}$ & $\begin{array}{c}0.272^{* *} \\
(0.112)\end{array}$ \\
\hline R-squared & & & & \\
\hline $\begin{array}{r}\text { Linear Flexible Slope } \\
\text { R-squared }\end{array}$ & $\begin{array}{c}0.561^{*} \\
(0.300) \\
0.487\end{array}$ & $\begin{array}{c}0.548^{*} \\
(0.301) \\
0.439\end{array}$ & $\begin{array}{c}0.0843^{* *} \\
(0.0376) \\
0.386\end{array}$ & $\begin{array}{c}0.228 * * \\
(0.105) \\
0.466\end{array}$ \\
\hline $\begin{array}{l}\text { Quadratic } \\
\text { R-squared }\end{array}$ & $\begin{array}{c}0.723^{* *} \\
(0.351) \\
0.487\end{array}$ & $\begin{array}{c}0.746^{* *} \\
(0.352) \\
0.434\end{array}$ & $\begin{array}{c}0.124^{* * * *} \\
(0.0475) \\
0.375\end{array}$ & $\begin{array}{c}0.274^{* *} \\
(0.128) \\
0.456\end{array}$ \\
\hline Outcome Mean & 0.580 & 0.263 & 0.035 & 0.170 \\
\hline & Panel B: & Per Capita & & \\
\hline Specification & $\begin{array}{l}\text { Affected } \\
\text { Persons }\end{array}$ & Fatalities & $\begin{array}{c}\text { Major } \\
\text { Incidents }\end{array}$ & $\begin{array}{c}\text { Total } \\
\text { Incidents }\end{array}$ \\
\hline $\begin{array}{r}\text { Linear } \\
\text { R-squared }\end{array}$ & $\begin{array}{c}2.393 * * \\
(1.135) \\
0.526\end{array}$ & $\begin{array}{c}1.852^{*} \\
(1.044) \\
0.522\end{array}$ & $\begin{array}{c}0.537^{* *} \\
(0.240) \\
0.562\end{array}$ & $\begin{array}{c}1.183^{* *} \\
(0.539) \\
0.683\end{array}$ \\
\hline $\begin{array}{r}\text { Linear Flexible Slope } \\
\text { R-squared }\end{array}$ & $\begin{array}{c}1.906^{*} \\
(1.047) \\
0.526\end{array}$ & $\begin{array}{c}1.536 \\
(1.113) \\
0.523\end{array}$ & $\begin{array}{c}0.391^{* *} \\
(0.187) \\
0.563\end{array}$ & $\begin{array}{c}0.959^{*} \\
(0.541) \\
0.685\end{array}$ \\
\hline $\begin{array}{l}\text { Quadratic } \\
\text { R-squared }\end{array}$ & $\begin{array}{c}2.277^{*} \\
(1.209) \\
0.526\end{array}$ & $\begin{array}{c}2.387^{*} \\
(1.275) \\
0.522\end{array}$ & $\begin{array}{c}0.602^{* *} \\
(0.246) \\
0.562\end{array}$ & $\begin{array}{c}1.060^{*} \\
(0.607) \\
0.684\end{array}$ \\
\hline Outcome Mean & 6.577 & 3.012 & 0.360 & 1.748 \\
\hline
\end{tabular}

Controls include baseline averages of each dependent variable and police force changes. Unit of observation is district-month. Regressions contain 3192 observations: 228 district-clusters (Phase 1 and Phase 2 districts) in $14 \mathrm{~m} \oplus 2$ ths post-Phase 1 implementation and pre-Phase 2 implementation. 
Table 4: Who Initiates the Attacks and Who is Killed

\begin{tabular}{|c|c|c|c|}
\hline & Panel A: & Who Initiates & \\
\hline Specification & $\begin{array}{c}\text { Police } \\
\text { on Maoist }\end{array}$ & $\begin{array}{c}\text { Maoist } \\
\text { on Police }\end{array}$ & $\begin{array}{c}\text { Maoist } \\
\text { on Civilians }\end{array}$ \\
\hline Linear & $\begin{array}{c}0.110^{*} \\
(0.0610)\end{array}$ & $\begin{array}{l}0.0250^{* *} \\
(0.0121)\end{array}$ & $\begin{array}{l}0.0945^{*} \\
(0.0496)\end{array}$ \\
\hline R-squared & 0.133 & 0.180 & 0.350 \\
\hline Linear Flexible Slope & $\begin{array}{c}0.0889^{*} \\
(0.0470) \\
0.140\end{array}$ & $\begin{array}{c}0.0218^{* *} \\
(0.0111) \\
0.181\end{array}$ & $\begin{array}{c}0.0626 \\
(0.0394) \\
0.357\end{array}$ \\
\hline Quadratic & $\begin{array}{c}0.100^{*} \\
(0.0607)\end{array}$ & $\begin{array}{l}0.0252^{*} \\
(0.0135)\end{array}$ & $\begin{array}{l}0.0898^{*} \\
(0.0528)\end{array}$ \\
\hline R-squared & 0.136 & 0.180 & 0.351 \\
\hline \multirow[t]{2}{*}{ Outcome Mean } & 0.057 & 0.028 & 0.071 \\
\hline & Panel B: & Who is Killed & \\
\hline Specification & $\begin{array}{l}\text { Civilians } \\
\text { Killed }\end{array}$ & $\begin{array}{l}\text { Police } \\
\text { Killed }\end{array}$ & $\begin{array}{c}\text { Maoists } \\
\text { Killed }\end{array}$ \\
\hline $\begin{array}{r}\text { Linear } \\
\text { R-squared }\end{array}$ & $\begin{array}{c}0.146 \\
(0.119) \\
0.337\end{array}$ & $\begin{array}{c}0.0456 \\
(0.0677) \\
0.176\end{array}$ & $\begin{array}{c}0.356^{* *} \\
(0.176) \\
0.204\end{array}$ \\
\hline $\begin{array}{r}\text { Linear Flexible Slope } \\
\text { R-squared }\end{array}$ & $\begin{array}{c}0.132 \\
(0.120) \\
0.337\end{array}$ & $\begin{array}{c}0.0339 \\
(0.0508) \\
0.176\end{array}$ & $\begin{array}{c}0.306^{* *} \\
(0.152) \\
0.211\end{array}$ \\
\hline $\begin{array}{l}\text { Quadratic } \\
\text { R-squared }\end{array}$ & $\begin{array}{c}0.168 \\
(0.140) \\
0.337\end{array}$ & $\begin{array}{c}0.0980 \\
(0.0749) \\
0.175\end{array}$ & $\begin{array}{c}0.394^{* *} \\
(0.200) \\
0.200\end{array}$ \\
\hline Outcome Mean & 0.095 & 0.079 & 0.089 \\
\hline
\end{tabular}

Panel A shows the results for 'who initiates the attacks and against whom.' Panel B reports the results for 'who is killed'.

See table 3 for additional notes. 43 
Table 5: The Short Run and the Medium Run

\begin{tabular}{|c|c|c|c|c|}
\hline & Panel A: & Short & Run & \\
\hline Specification & $\begin{array}{l}\text { Affected } \\
\text { Persons }\end{array}$ & Fatalities & $\begin{array}{c}\text { Major } \\
\text { Incidents }\end{array}$ & $\begin{array}{c}\text { Total } \\
\text { Incidents }\end{array}$ \\
\hline Linear & $\begin{array}{c}0.778^{* *} \\
(0.383)\end{array}$ & $\begin{array}{c}0.641^{* *} \\
(0.322)\end{array}$ & $\begin{array}{c}0.123^{* *} \\
(0.0552)\end{array}$ & $\begin{array}{l}0.273^{*} \\
(0.142)\end{array}$ \\
\hline R-squared & 0.655 & 0.599 & 0.510 & 0.577 \\
\hline Linear Flexible Slope & $\begin{array}{l}0.760^{*} \\
(0.420)\end{array}$ & $\begin{array}{c}0.671^{*} \\
(0.364) \\
0.598\end{array}$ & $\begin{array}{c}0.113^{*} \\
(0.0585)\end{array}$ & $\begin{array}{c}0.251^{*} \\
(0.139) \\
0.581\end{array}$ \\
\hline Quadratic & $\begin{array}{c}0.967^{* *} \\
(0.488) \\
0654\end{array}$ & $\begin{array}{c}0.855^{* *} \\
(0.425) \\
0.595\end{array}$ & $\begin{array}{c}0.162^{* *} \\
(0.0712) \\
0.501\end{array}$ & $\begin{array}{c}0.311^{*} \\
(0.170) \\
0.571\end{array}$ \\
\hline & Panel B: & Medium & Run & \\
\hline Specification & $\begin{array}{l}\text { Affected } \\
\text { Persons }\end{array}$ & Fatalities & $\begin{array}{l}\text { Major } \\
\text { Incidents }\end{array}$ & $\begin{array}{c}\text { Total } \\
\text { Incidents }\end{array}$ \\
\hline Linear & $\begin{array}{l}0.484^{*} \\
(0.273)\end{array}$ & $\begin{array}{c}0.458^{* *} \\
(0.222)\end{array}$ & $\begin{array}{c}0.0855^{* *} \\
(0.0371)\end{array}$ & $\begin{array}{c}0.273^{* * *} \\
(0.106)\end{array}$ \\
\hline Linear Flexible Slope & $\begin{array}{c}0.396^{*} \\
(0.233) \\
0.359\end{array}$ & $\begin{array}{c}0.397^{*} \\
(0.223) \\
0.361\end{array}$ & $\begin{array}{c}0.0639^{* *} \\
(0.0285) \\
0.279\end{array}$ & $\begin{array}{c}0.224^{* *} \\
(0.0955) \\
0.381\end{array}$ \\
\hline $\begin{array}{l}\text { Quadratic } \\
\text { R-squared }\end{array}$ & $\begin{array}{c}0.445 \\
(0.281) \\
0.359\end{array}$ & $\begin{array}{c}0.520^{* *} \\
(0.259) \\
0.358\end{array}$ & $\begin{array}{c}0.0862^{* *} \\
(0.0361) \\
0.273\end{array}$ & $\begin{array}{c}0.240^{* *} \\
(0.108) \\
0.376\end{array}$ \\
\hline Outcome Mean & 0.580 & 0.263 & 0.035 & 0.170 \\
\hline
\end{tabular}

Panel A shows Short Run impacts (months 1 through 7 after implementations). Panel B shows the Medium Run (months 8 through 14 after implementation).

Controls include baseline averages of each dependent variable and police force changes. Unit of observation is district-month. Regressions contain 1596 observations: 228 district-clusters (Phase 1 and Phase 2 districts) in the 7 month periods. See Table 3 for additional notes. 
Table 6: Who Initiates the Attacks: Star States vs Non-Star States

\begin{tabular}{|c|c|c|c|}
\hline Specification & $\begin{array}{c}\text { Police } \\
\text { on Maoist }\end{array}$ & $\begin{array}{c}\text { Maoist } \\
\text { on Police }\end{array}$ & $\begin{array}{c}\text { Maoist } \\
\text { on Civilians }\end{array}$ \\
\hline \multicolumn{4}{|l|}{ Linear: } \\
\hline NREGS & $\begin{array}{c}0.0609 \\
(0.0380)\end{array}$ & $\begin{array}{c}0.0294^{* *} \\
(0.0141)\end{array}$ & $\begin{array}{c}0.0735^{*} \\
(0.0390)\end{array}$ \\
\hline NREGS*Star States & $0.116^{*}$ & $\begin{array}{c}-0.0130 \\
(0.00899)\end{array}$ & $\begin{array}{c}0.0593 \\
(0.0560)\end{array}$ \\
\hline Star States & $\begin{array}{c}-0.0136 \\
(0.0170)\end{array}$ & $\begin{array}{l}0.00688^{*} \\
(0.00380)\end{array}$ & $\begin{array}{l}-0.0305 \\
(0.0269)\end{array}$ \\
\hline R-squared & 0.136 & 0.181 & 0.351 \\
\hline \multicolumn{4}{|l|}{ Linear Flexible Slope: } \\
\hline NREGS & $\begin{array}{c}0.0257 \\
(0.0217)\end{array}$ & $\begin{array}{l}0.0228^{*} \\
(0.0127)\end{array}$ & $\begin{array}{c}0.0244 \\
(0.0200)\end{array}$ \\
\hline NREGS*Star States & $\begin{array}{l}0.363^{* *} \\
(0.174)\end{array}$ & $\begin{array}{c}0.0312 \\
(0.0328)\end{array}$ & $\begin{array}{c}0.190 \\
(0.126)\end{array}$ \\
\hline Star States & $\begin{array}{l}-0.0222 \\
(0.0193)\end{array}$ & $\begin{array}{c}0.00597 \\
(0.00376)\end{array}$ & $\begin{array}{l}-0.0372 \\
(0.0279)\end{array}$ \\
\hline $\mathrm{R}$-squared & 0.153 & 0.185 & 0.362 \\
\hline \multicolumn{4}{|l|}{ Quadratic: } \\
\hline NREGS & $\begin{array}{c}0.0592 \\
(0.0398)\end{array}$ & $\begin{array}{c}0.0298^{* *} \\
(0.0151)\end{array}$ & $\begin{array}{l}0.0681^{*} \\
(0.0401)\end{array}$ \\
\hline NREGS*Star States & $\begin{array}{c}0.116^{*} \\
(0.0675)\end{array}$ & $\begin{array}{l}-0.0130 \\
(0.00870)\end{array}$ & $\begin{array}{c}0.0602 \\
(0.0548)\end{array}$ \\
\hline Star States & $\begin{array}{l}-0.0139 \\
(0.0166)\end{array}$ & $\begin{array}{c}0.00695 \\
(0.00429)\end{array}$ & $\begin{array}{l}-0.0314 \\
(0.0260)\end{array}$ \\
\hline R-squared & 0.137 & 0.181 & 0.352 \\
\hline Outcome Mean & 0.057 & 0.028 & 0.071 \\
\hline
\end{tabular}

Star States include Andhra Pradesh, Chhattisgarh, Tamil Nadu, Rajasthan and Madhya Pradesh, which according to field reports have a higher implementation quality of the NREGS than other states (Dreze and Khera 2009, Khera 2011).

Controls include baseline averages of each dependent variable and police force changes. Unit of observation 4 s district-month. Regressions contain 3192 observations: 228 district-clusters (Phase 1 and Phase 2 districts) in 14 months post-Phase 1 implementation and pre-Phase 2 implementation. 
Figure 1: Red Corridor Districts and NREGS Phase

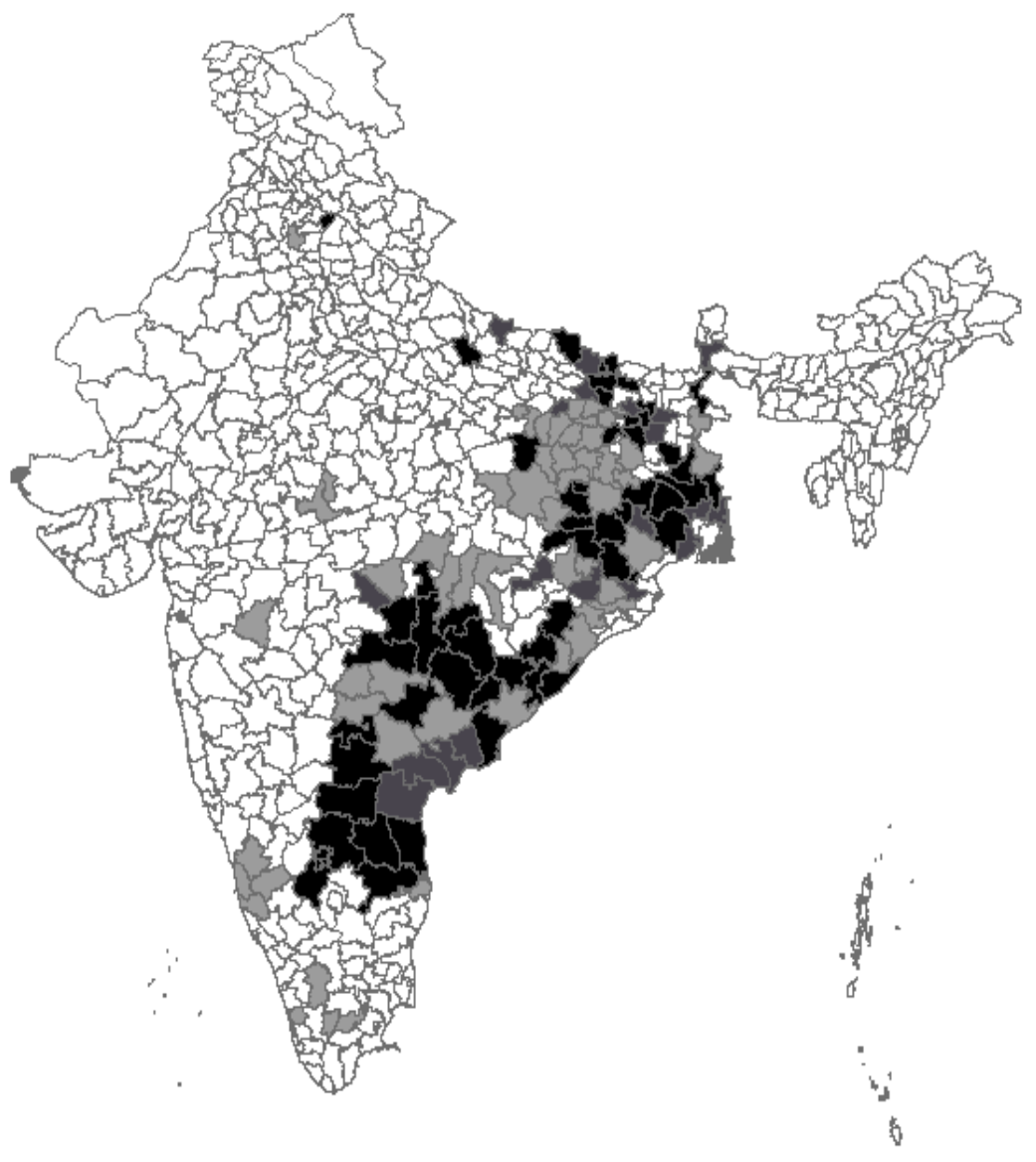

Note: Red corridor districts are districts that had at least one Naxalite incident in the analysis period (January 2005-March 2008). Red corridor districts predicted to receive NREGS in the first, second, and third phase based on the algorithm are in black, dark grey, and light grey, respectively. 
Figure 2: Distribution of Index and Discontinuities by Phase

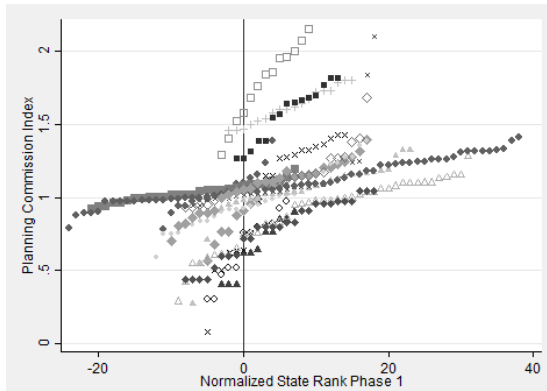

(a) Distribution of Index - Phase

1

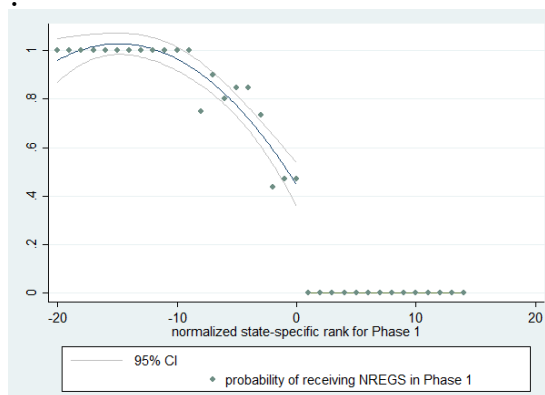

(c) Phase 1 Discontinuity

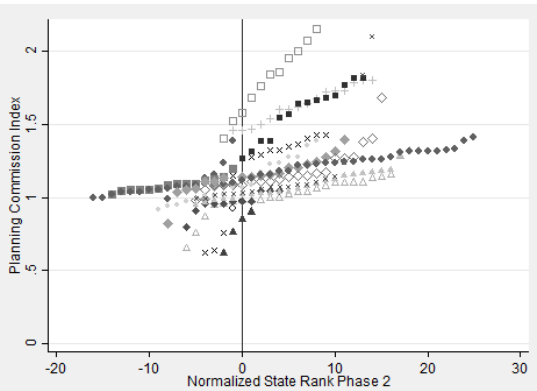

(b) Distribution of Index - Phase 2

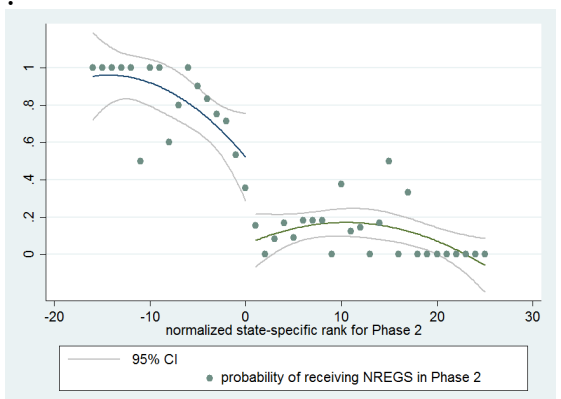

(d) Phase 2 Discontinuity

Note: First row plots the distribution of the index by state. Second row shows the treatment discontinuities for each phase, dropping the phase far away from the cutoff (Phase 3 in (c), Phase 1 in (d)). Negative and zero normalized state rank numbers are districts that should have received NREGS based on the government algorithm, whereas positive numbers are assigned to districts that should have been ineligible. 
Figure 3: Pre-Treatment Discontinuities for Main Variables
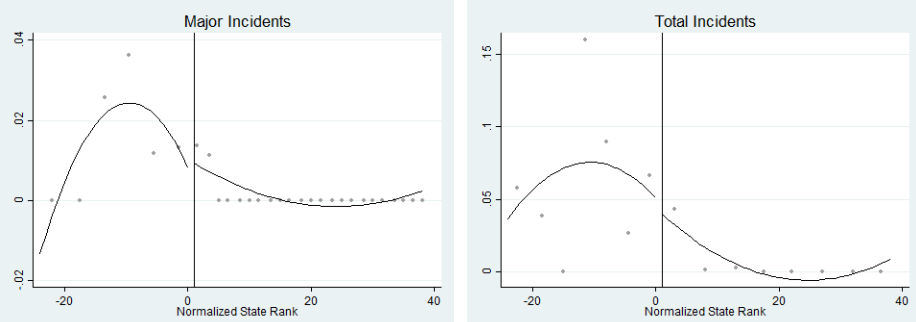

(a) Total Number of Major (b) Total Number of InciIncidents

dents
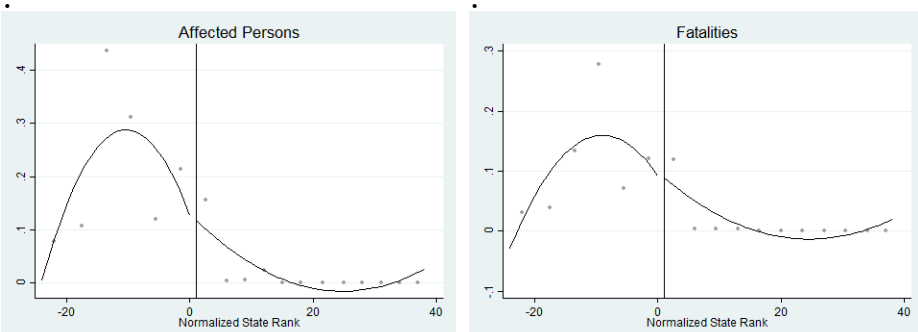

(c) Persons Killed, Injured, (d) Total Number of PerAbducted or Captured sons Killed
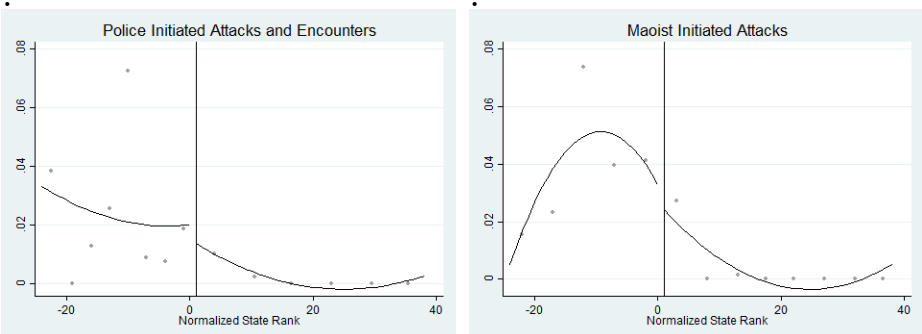

(e) Police Initiated Attacks (f) Maoist Initiated Attacks

Note: The graphs use the optimal quantile-spaced binning procedure suggested by Calonico et al. (Forthcoming). Polynomials are fitted through the underlying data and not just the bins. Negative and zero normalized state rank numbers are districts that should have received NREGS based on the government algorithm, whereas positive numbers are assigned to the districts that should have been ineligible according to the district ranking. The sample is restricted to the time period before the first phase NREGS implementation. A version of this graph without outliers can be found below. 


\section{Figure 4: Discontinuities for Main Variables}

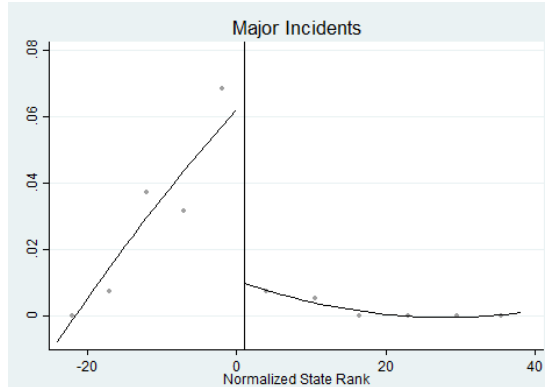

(a) Total Number of Major Incidents

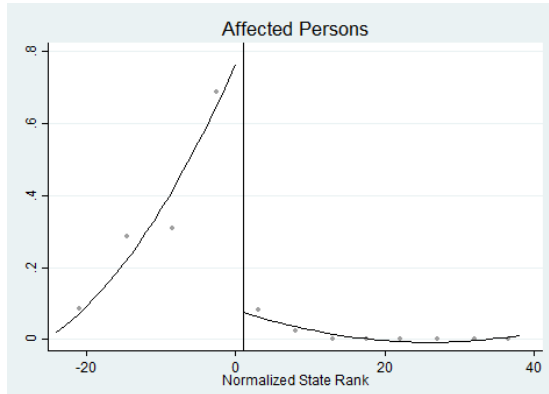

(c) Persons Killed, Injured, Ab- (d) ducted or Captured

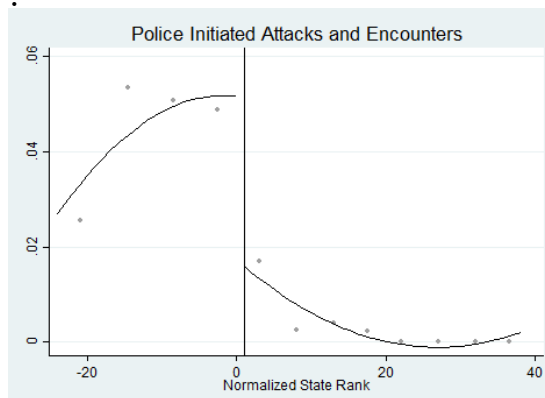

(e) Police Initiated Attacks

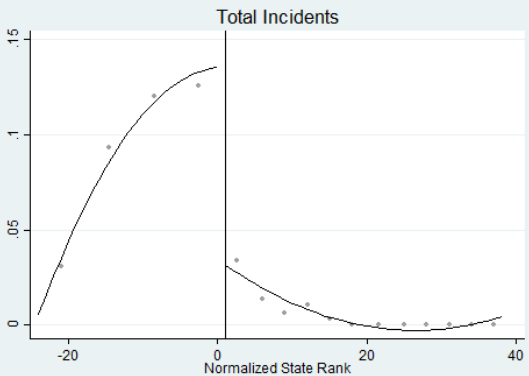

(b) Total Number of Incidents

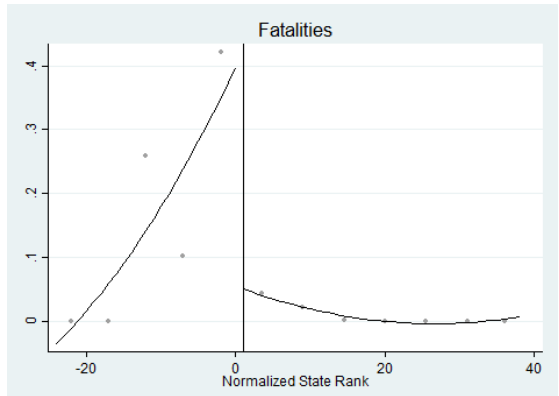

(d) Total Number of Persons Killed

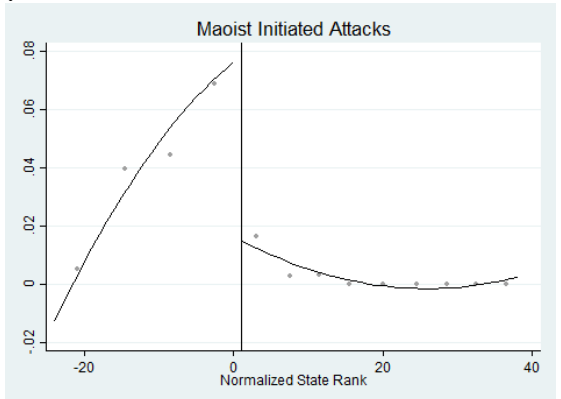

(f) Maoist Initiated Attacks

Note: The graphs use the optimal quantile-spaced binning procedure suggested by Calonico et al. (Forthcoming). Polynomials are fitted through the underlying data and not just the bins. Unit of observation is a district-month, with 228 districts across a 14-month period post Phase 1 implementation and pre Phase 2 implementation. See appendix for a version of this graph without outliers. 
Figure 5: Monthly RD Coefficients - Total Number of Incidents

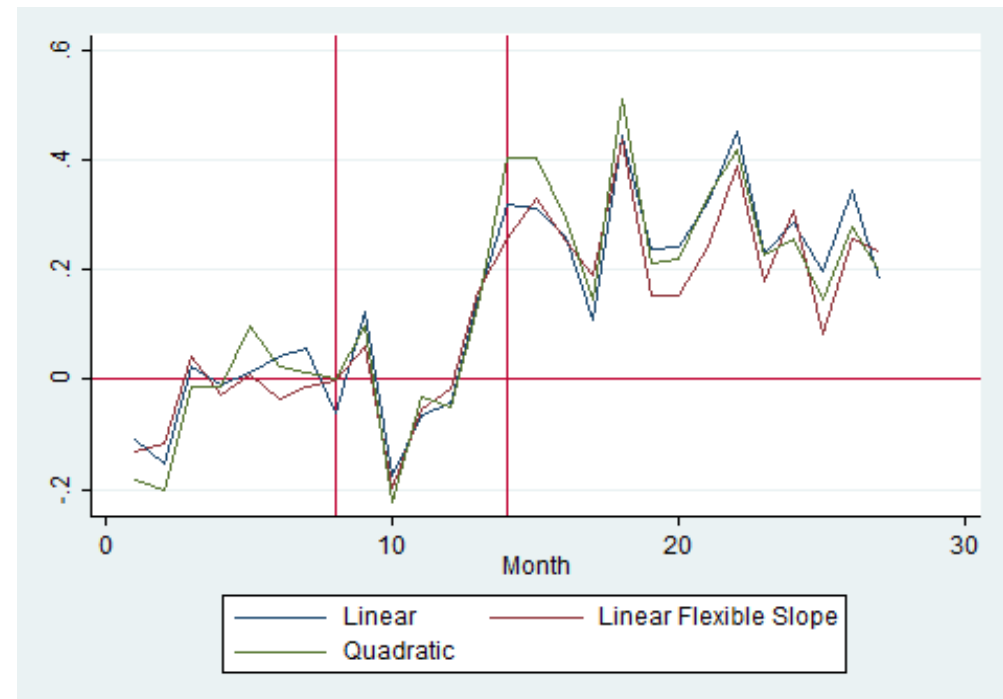

Figure 6: Monthly RD Coefficients - Number of Persons Affected

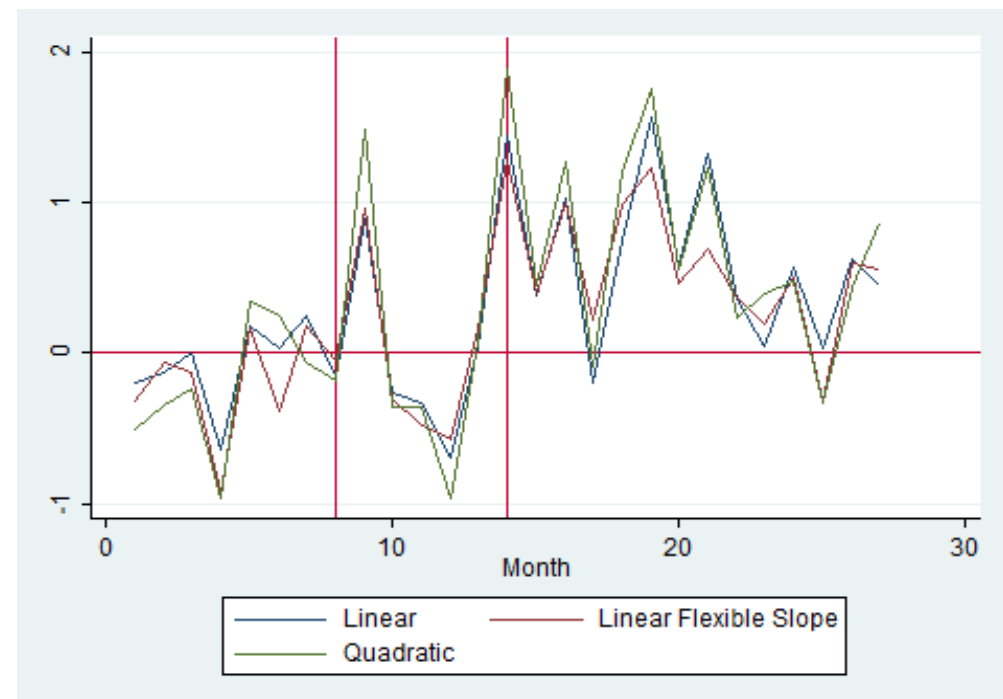

Note: Coefficients of month-by-month RD regressions of number of incidents and number of persons affected. The first vertical line indicates the passage of the Act in Parliament, the second vertical line indicates the first month of implementation in Phase 1. Our analysis ends 14 months after program implementation when implementation started in Phase 2 districts. Each point is the coefficient for a different regression restricting the sample to the corresponding month. 


\section{A Appendix (Not for Publication): Additional Background Information, Tables and Fig- ures}

\section{A.1 The Maoist Movement and NREGS}

Naxalites have been operating since 1967 when landlords attacked a tribal villager in the village of Naxalbari in West Bengal and triggered an uprising. By the early 1970s, the movement had spread to other parts of the country. In 2004, the two biggest previously competing Naxalite groups joined hands to form the Communist Party of India (Maoist) in 2004. This is believed to have substantially exacerbated India's problem with the Naxalites and to have driven the recent growth in violence (Lalwani 2011). The main responsibility in the fight of Maoists and the Indian government rests with the civil and paramilitary forces of the state police in the affected areas, although they are often supported by central paramilitary battalions. Many observers refer to the often widespread disregard for local perceptions as well as the sometimes excessively brutal nature of police force behavior that affects many civilians. These destroy not only the trust of the local population in the Indian state but also the opportunity for police forces to take advantage of information on insurgents and other forms of assistance provided by the people (Bakshi 2009, Lalwani 2011, Sundar 2011). There is some evidence that insurgents in turn provide civilians with some help, for example in the form of teaching them more effective farming techniques (Mukherji 2012). Naxalites also claim to protect civilians from exploitation by large mining conglomerates (Borooah 2007).

The fight against the Maoists is inextricably related to the political sphere, with the state and central governments using their political and military influence to intensify the crackdown. With a change of guard at the Ministry of Home Affairs, "Operation Greenhunt" was launched in 2009 supported by state forces as an "all-out offensive" against the rebels. ${ }^{34}$ At around the same time, political parties in West Bengal accused each other of allying with Maoists during the state elections. ${ }^{35}$ Of the many instances of government and political parties involved in the crackdown, one of the most controversial has been the formation of a civilian militia called the Salwa Judum by the Chhattis-

\footnotetext{
${ }^{34}$ Sethi, Aman (6 February 2013). "Green Hunt: the anatomy of an operation". The Hindu

${ }^{35}$ South Asian Terrorism Portal: www.satp.org/satporgtp/countries/india/maoist/Assessment/2013/westbengal.html
} 
garh state government in 2005. The group was led by the elected Leader of the Opposition and whole-heartedly supported by the party in power (Mukherji 2012). Civilians and tribals were armed and encouraged to participate since they were thought to have better information. In 2011, the Supreme Court disbanded the group on the grounds that it was unconstitutional. For civilians, all of these instances mean that it may often be difficult to clearly distinguish between police actions and broader strategies by the state.

Sabotage of the program by the Naxalites does not seem to be a large-scale problem for the working of NREGS: In contrast to a number of other government schemes, chief secretaries from the seven states most heavily affected by Naxalite violence believe NREGS to work relatively well in their districts. ${ }^{36}$ Case studies in Jharkhand, Chhattisgarh and Orissa come to a similar conclusion (Banerjee and Saha 2010). In our manual coding of all incidents of Maoist violence used in this paper there was also no incident that targeted a NREGS worksite. There is some evidence for other forms of interference with the implementation of NREGS, however, such as influencing the types of projects undertaken under NREGS by threatening to destroy infrastructure projects or extorting payments from NREGS work (see e.g. Parashar 2013 for a case study).

\section{A.2 Conflict Dataset Information}

The primary source of data used in this paper comes from the South Asian Terrorism Portal (SATP). This is a website managed by a registered non-profit, non-governmental organization called the Institute of Conflict Management in New Delhi. The Institute provides consultancy services to governments and does extensive research on insurgency-related activities.

We manually code the initiating party of each incident where this is possible. An example of a police-initiated attack in the newspaper reports is this incident: "Chhattisgarh, 2006: July 7 Central Reserve Police Force personnel raided a CPI-Maoist hideout under Basaguda police station in the Dantewada district and shot dead seven Maoists." On the other hand, a typical Maoist attack aimed at government troops reads like this: "West Bengal, 2006: February 26 Cadres of the CPI-Maoist detonate a landmine blowing up a police vehicle that killed four persons, including two security force (SF) personnel, at Naakrachhara in the West Midnapore district.' Lastly, incidents like the following one are labeled as a Maoist-initiated attack against civilians: "Andhra Pradesh, 200\%: November 16 Three persons, including two migrant

\footnotetext{
${ }^{36}$ The Times of India, April 14, 2010: Naxals backing NREGA?
} 
tribals from the Bastar region of Chhattisgarh, were killed by cadres of the CPI-Maoist in Narsingpet village of Chintoor mandal in Khammam district. Before the killing, the Maoists reportedly grilled them in the presence of the villagers by organizing a panchayati (village level meeting) and branded them as police informants.'

A number of incidents also contain information related to police informers: See e.g. www.satp.org for the following press releases from 2007: "Cadres of the CPI-Maoist shot dead a 45-year-old shopkeeper at Sringeri in the Chikmagalur District, suspecting him to be a Police informer... Before fleeing, they left behind pamphlets with a message that read: 'Let us expose informers and teach them a befitting lesson." "Two brothers were killed at Tamba village by the CPIMaoist cadres on suspicion of being Police informers... More than 20 Police informers have reportedly been killed in the last one year in Jharkhand."

According to a press report from 2007, for example: "The CPI-Maoist reportedly issued a press release at Chintapalli village in the Visakhapatnam District, blaming the Police for turning the Girijans (local tribals) into informers by spending huge amounts of money... (and) that surrendered Maoists are helping the Police, were not leading a normal life and were always with the Police who provided them with all luxuries and used them in combing operations..." (www.satp.org)

As is common with this kind of dataset, there are certain limitations to using it: The number of Naxalites killed or injured is difficult to verify and may be incomplete, and security forces may have an incentive to overstate their accomplishments by inflating the numbers. This concern is mitigated to some degree by the fact that police are required to disclose names and ranks of the Maoists killed to validate their reports and that we make use of incidents reported in the media rather than administrative data.

The potential data quality limitations introduce measurement error into the analysis, but will not systematically bias our regression discontinuity (RD) results unless reporting standards on Naxalite violence are systematically correlated with the predicted treatment status of NREGS according to the government algorithm. Such a correlation may occur if the spotlight theory holds and the police face external pressures to perform better in treatment areas than in control districts. In the empirical results section, we provide evidence against the spotlight theory by analyzing which parties initiated incidents and by looking at other types of violence and crime. 
Table A.7: Education, Employment and Wages at Baseline

\begin{tabular}{|c|c|c|c|c|}
\hline & HH Agri Labor & HH Self-emp in Agri & Pvt Wage & Pvt Wage Ext \\
\hline Linear & -0.102 & -0.00495 & 9.571 & 1.864 \\
\hline & $(0.0775)$ & $(0.0748)$ & $(8.120)$ & $(3.903)$ \\
\hline R-squared & 0.067 & 0.120 & 0 & 0.118 \\
\hline \multirow[t]{3}{*}{ Linear Flex Slope } & $-0.139 *$ & 0.121 & -0.260 & -6.352 \\
\hline & $(0.0803)$ & $(0.0784)$ & $(5.807)$ & $(3.863)$ \\
\hline & 0.003 & 0.036 & 0.109 & 0.114 \\
\hline \multirow[t]{2}{*}{ Quadratic } & -0.142 & 0.0913 & 7.998 & -2.986 \\
\hline & $(0.0976)$ & $(0.0908)$ & $(9.051)$ & $(4.553)$ \\
\hline \multirow[t]{2}{*}{ R-squared } & 0.019 & 0.119 & 0 & 0.188 \\
\hline & Education & Pvt Emp & Public Emp & Emp in Family Work \\
\hline \multirow[t]{2}{*}{ Linear } & 0.351 & 0.0191 & -0.00141 & -0.0590 \\
\hline & $(0.330)$ & $(0.0616)$ & $(0.00305)$ & $(0.0668)$ \\
\hline R-squared & 0 & 0.116 & 0 & 0.086 \\
\hline \multirow[t]{2}{*}{ Linear Flex Slope } & 0.282 & -0.0939 & -0.00111 & 0.0938 \\
\hline & $(0.338)$ & $(0.0654)$ & $(0.00262)$ & $(0.0683)$ \\
\hline R-squared & 0.022 & 0 & 0 & 0.056 \\
\hline \multirow[t]{2}{*}{ Quadratic } & 0.395 & -0.0622 & -0.00433 & 0.0536 \\
\hline & $(0.400)$ & $(0.0764)$ & $(0.00337)$ & $(0.0785)$ \\
\hline R-squared & 0 & 0.088 & 0 & 0.151 \\
\hline
\end{tabular}

Regressions of the form $y_{i j}=\beta_{0}+\beta_{1}$ nregs $_{i}+f($ rank, nregs $)+\epsilon_{i j}$ where $y_{i j}$ is an outcome variable of interest in district $i$ and month $j$, and the coefficient of interest is $\beta_{1}$. The function $f($.$) is either linear, linear with$ flexible slopes or quadratic. Regressions of baseline variables across 225 districts that are in either Phase 1 or 2 of the program. 
Figure A.7: Discontinuities for Non-Outcome Variables at Baseline
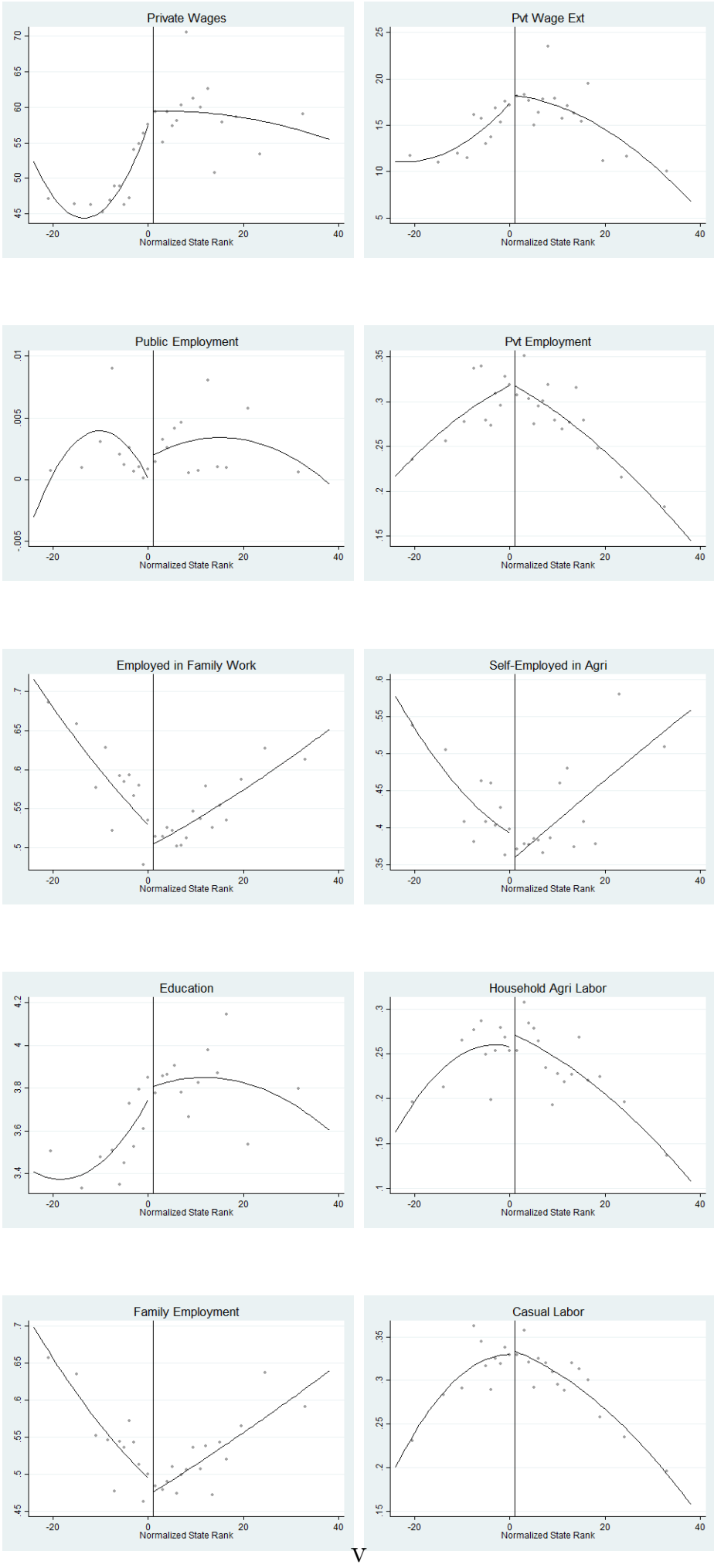
Table A.8: Other Types of Crime and Violence: Phase 1

\begin{tabular}{r|cccccc}
\hline & total crimes & murder & kidnapping & theft & burglary & riots \\
\hline \multirow{3}{*}{ Linear } & 1,287 & 13.63 & 33.93 & -30.27 & -28.09 & -107.2 \\
& $(945.6)$ & $(39.51)$ & $(30.07)$ & $(174.8)$ & $(93.75)$ & $(115.4)$ \\
R squared & 0.943 & 0.778 & 0.820 & 0.910 & 0.882 & 0.774 \\
& & & & & & \\
\hline Linear Flexible & 754.8 & 28.72 & 28.70 & -39.61 & -68.79 & -86.29 \\
& $(924.1)$ & $(35.76)$ & $(29.43)$ & $(189.1)$ & $(93.69)$ & $(107.9)$ \\
R squared & 0.947 & 0.776 & 0.820 & 0.911 & 0.882 & 0.775 \\
& & & & & & \\
\hline Quadratic & 988.9 & 55.56 & 29.78 & -36.06 & -42.57 & -122.9 \\
& $(1,134)$ & $(48.31)$ & $(34.59)$ & $(220.3)$ & $(115.3)$ & $(129.8)$ \\
R squared & 0.945 & 0.771 & 0.820 & 0.911 & 0.882 & 0.772 \\
& & & & & & \\
\hline Outcome mean & 2768.17 & 57.23 & 38.10 & 325.04 & 122.18 & 105.36 \\
\hline
\end{tabular}

Regressions contains 225 observations, where the unit of observation is a district. Source: Home Ministry of India 
Table A.9: Phase 2 - While Phase 1 is Treated and Phase 2 Treatment

\begin{tabular}{|c|c|c|c|c|}
\hline & Panel A: & During & Phase 1 & Treatment \\
\hline Specification & $\begin{array}{l}\text { Affected } \\
\text { Persons }\end{array}$ & Fatalities & $\begin{array}{c}\text { Major } \\
\text { Incidents }\end{array}$ & $\begin{array}{c}\text { Total } \\
\text { Incidents }\end{array}$ \\
\hline $\begin{array}{r}\text { Linear } \\
\text { R-squared }\end{array}$ & $\begin{array}{c}0.131^{* *} \\
(0.0537) \\
0.137\end{array}$ & $\begin{array}{c}0.0825^{*} \\
(0.0435) \\
0.141\end{array}$ & $\begin{array}{c}0.00345 \\
(0.00434) \\
0.206\end{array}$ & $\begin{array}{c}0.0348^{* * *} \\
(0.0122) \\
0.309\end{array}$ \\
\hline $\begin{array}{r}\text { Linear Flexible Slope } \\
\text { R-squared }\end{array}$ & $\begin{array}{c}0.208^{*} \\
(0.113) \\
0.090\end{array}$ & $\begin{array}{c}0.129 * \\
(0.0739) \\
0.103\end{array}$ & $\begin{array}{c}0.0109 \\
(0.00910) \\
0.191\end{array}$ & $\begin{array}{c}0.0434^{*} \\
(0.0236) \\
0.296\end{array}$ \\
\hline $\begin{array}{l}\text { Quadratic } \\
\text { R-squared }\end{array}$ & $\begin{array}{c}0.183^{* *} \\
(0.0925) \\
0.128\end{array}$ & $\begin{array}{c}0.114^{*} \\
(0.0625) \\
0.134\end{array}$ & $\begin{array}{c}0.00992 \\
(0.00717) \\
0.203\end{array}$ & $\begin{array}{c}0.0425^{* *} \\
(0.0199) \\
0.305\end{array}$ \\
\hline & Panel B: & Phase 2 & Treatment & Period \\
\hline Specification & $\begin{array}{l}\text { Affected } \\
\text { Persons }\end{array}$ & Fatalities & $\begin{array}{c}\text { Major } \\
\text { Incidents }\end{array}$ & $\begin{array}{c}\text { Total } \\
\text { Incidents }\end{array}$ \\
\hline $\begin{array}{r}\text { Linear } \\
\text { R-squared }\end{array}$ & $\begin{array}{c}-0.161 \\
(0.194) \\
0.055\end{array}$ & $\begin{array}{c}-0.180 \\
(0.168) \\
0.038\end{array}$ & $\begin{array}{c}-0.00620 \\
(0.00906) \\
0.044\end{array}$ & $\begin{array}{c}0.00399 \\
(0.0307) \\
0.184\end{array}$ \\
\hline $\begin{array}{r}\text { Linear Flexible Slope } \\
\text { R-squared }\end{array}$ & $\begin{array}{c}-0.0331 \\
(0.232) \\
0.055\end{array}$ & $\begin{array}{c}-0.137 \\
(0.173) \\
0.040\end{array}$ & $\begin{array}{c}-0.00650 \\
(0.00908) \\
0.043\end{array}$ & $\begin{array}{c}0.0327 \\
(0.0462) \\
0.178\end{array}$ \\
\hline $\begin{array}{l}\text { Quadratic } \\
\text { R-squared }\end{array}$ & $\begin{array}{c}-0.0702 \\
(0.200) \\
0.058\end{array}$ & $\begin{array}{c}-0.134 \\
(0.157) \\
0.040\end{array}$ & $\begin{array}{c}-0.00562 \\
(0.00809) \\
0.044\end{array}$ & $\begin{array}{c}0.0237 \\
(0.0377) \\
0.185\end{array}$ \\
\hline Outcome Mean & 0.580 & 0.263 & 0.035 & 0.170 \\
\hline
\end{tabular}

Panel A contains impacts on Phase 2 districts during February 2006 and March 2007. During this period, Phase 1 received NREGS, and Phase 2 did not. The regressions contain 3178 observations: 227 district-clusters (Phase 2 and Phase 3 districts) in 14 months post-Phase 1 implementation and pre-Phase 2 implementation. Panel B shows the impact on Phase 2 districts during A vilil 2007 and March 2008. During this period, Phase 2 also received NREGS. Regressions contain 2497 observations: 227 districtclusters (Phase 2 and Phase 3 districts) in 11 months post-Phase 2 implementation and pre-Phase 3 implementation. Controls include baseline averages of each dependent variable and police force changes. Unit of observation is district-month. "Affected Persons" indicates number of persons killed, injured, abducted or captured. "Fatalities" indicates total number of deaths. "Major Incidents" indicates number of 'Major Incidents' 
Figure A.8: Without Outliers: Main Results

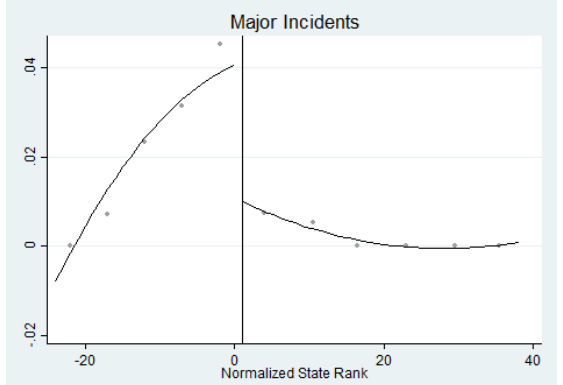

(a) Total Number of Major Incidents

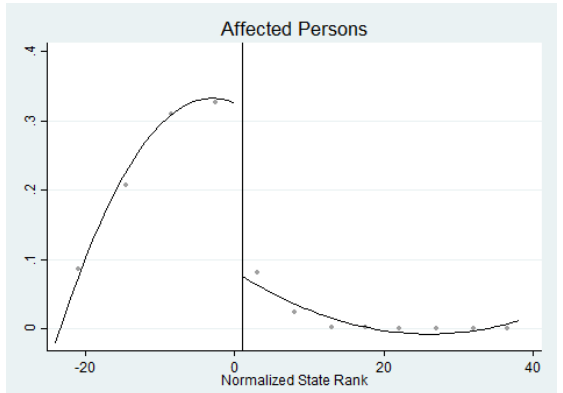

(c) Persons Killed, Injured, Abducted or Captured

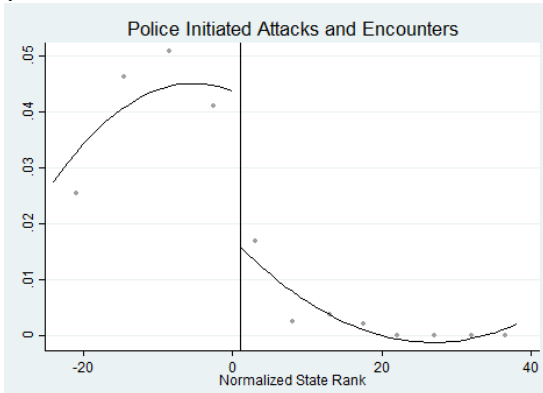

(e) Police Initiated Attacks

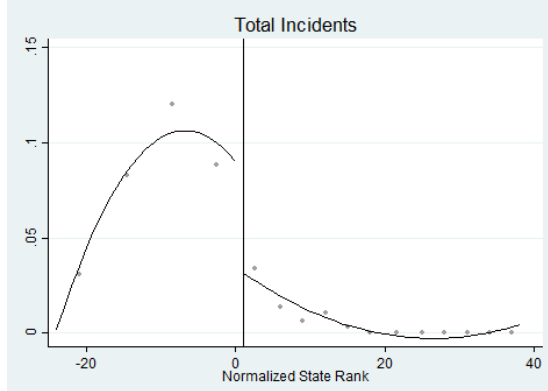

(b) Total Number of Incidents

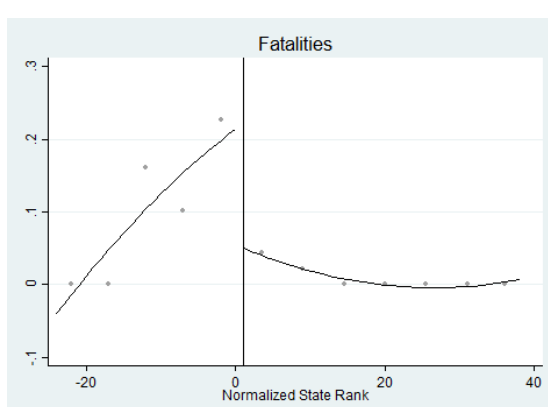

(d) Total Number of Persons Killed

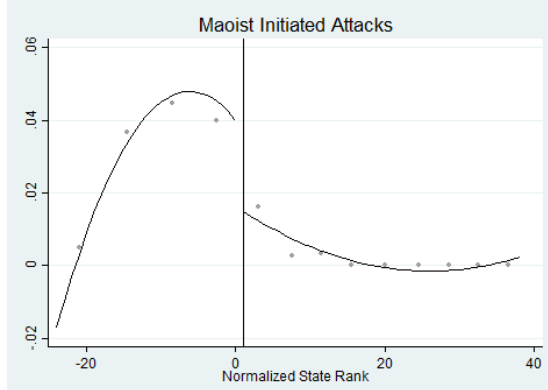

(f) Maoist Initiated Attacks

Note: Outlier observations (more than 20 affected persons a month) are dropped. 
Table A.10: Main Results: Without Biggest Incidents (Outliers)

\begin{tabular}{|c|c|c|c|c|}
\hline Specification & $\begin{array}{l}\text { Affected } \\
\text { Persons }\end{array}$ & Fatalities & $\begin{array}{c}\text { Major } \\
\text { Incidents }\end{array}$ & $\begin{array}{c}\text { Total } \\
\text { Incidents }\end{array}$ \\
\hline Linear & $0.373^{* *}$ & $0.376^{* *}$ & $0.0724^{* *}$ & 0.173 *** \\
\hline R-squared & 0.320 & 0.311 & 0.202 & 0.358 \\
\hline \multirow[t]{3}{*}{ Linear Flexible Slope } & $0.323^{* *}$ & $0.344^{* *}$ & $0.0553^{* * *}$ & $0.145^{* * *}$ \\
\hline & $(0.148)$ & $(0.169)$ & $(0.0211)$ & $(0.0551)$ \\
\hline & 0.321 & 0.312 & 0.207 & 0.364 \\
\hline \multirow[t]{2}{*}{ Quadratic } & $0.383^{* *}$ & $0.460 * *$ & $0.0795 * * *$ & $0.162^{* *}$ \\
\hline & $(0.193)$ & $(0.205)$ & $(0.0299)$ & $(0.0657)$ \\
\hline R-squared & 0.320 & 0.309 & 0.199 & 0.360 \\
\hline Outcome Mean & 0.580 & 0.263 & 0.035 & 0.170 \\
\hline
\end{tabular}

Dropping outlier incidents - large attacks by Maoists or police that affect (kill/injure) more than 20 persons at a time. These eliminate the deadliest 11 district-month observations. Robust to using other cutoffs. Controls include baseline averages of each dependent variable and police force changes. Unit of observation is district-month. Regressions contain 3184 observations: 228 district-clusters (Phase 1 and Phase 2 districts) in 14 months post-Phase 1 implementation and pre-Phase 2 implementation. 
Table A.11: Who Initiates the Attacks and Who is Killed (Per Capita)

\begin{tabular}{r|ccc}
\hline & Panel A: & Who Initiates the Attacks & \\
\hline Specification & $\begin{array}{c}\text { Police } \\
\text { on Maoist }\end{array}$ & $\begin{array}{c}\text { Maoist } \\
\text { on Police }\end{array}$ & $\begin{array}{c}\text { Maoist } \\
\text { on Civilians }\end{array}$ \\
\hline Linear & $0.975^{* *}$ & 0.133 & $0.491^{* *}$ \\
& $(0.412)$ & $(0.101)$ & $(0.227)$ \\
\hline Linear Flexible Slope & $0.741^{* *}$ & 0.153 & 0.254 \\
& $(0.375)$ & $(0.107)$ & $(0.171)$ \\
\hline Quadratic & $0.779^{*}$ & 0.102 & $0.436^{* *}$ \\
& $(0.424)$ & $(0.0957)$ & $(0.208)$ \\
\hline \hline Outcome Mean & 0.578 & 0.329 & 0.753 \\
\hline & Panel B: & Who is Killed & \\
\hline Specification & Civilians & Police & Maoists \\
& Killed & Killed & Killed \\
\hline Linear & 0.531 & -0.232 & $2.051^{* * *}$ \\
& $(0.716)$ & $(0.632)$ & $(0.755)$ \\
\hline Linear Flexible Slope & 0.358 & -0.148 & $\left(.613^{* *}\right.$ \\
& $(0.561)$ & $(0.372)$ & $2.137^{* *}$ \\
\hline Quadratic & 0.595 & 0.201 & $(0.897)$ \\
& $(0.706)$ & $(0.637)$ & 0.956 \\
\hline Outcome Mean & 1.099 & 0.958 &
\end{tabular}

Results are per-10 million people (based on population counts from the 2001 Census). Panel A gives the results for 'who initiates the attacks and against whom.' Panel B shows the results for 'who is killed'. Controls include baseline averages of each dependent variable and police force changes. Unit of observation is district-month. Regressions contain 3192 observations: 228 district-clusters (Phase 1 and Phase 2 districts) in 14 months post-Phase 1 implementation and pre-Phase 2 implementation. 
Table A.12: Donut Hole and Varying the Bandwidth

\begin{tabular}{|c|c|c|c|c|}
\hline & Panel A: & Donut & Hole & \\
\hline Specification & $\begin{array}{l}\text { Affected } \\
\text { Persons }\end{array}$ & Fatalities & $\begin{array}{c}\text { Major } \\
\text { Incidents }\end{array}$ & $\begin{array}{c}\text { Total } \\
\text { Incidents }\end{array}$ \\
\hline $\begin{array}{r}\text { Linear } \\
\text { R-squared }\end{array}$ & $\begin{array}{c}0.562^{*} \\
(0.311) \\
0.494\end{array}$ & $\begin{array}{c}0.475^{*} \\
(0.283) \\
0.458\end{array}$ & $\begin{array}{c}0.0869^{* *} \\
(0.0405) \\
0.407\end{array}$ & $\begin{array}{c}0.287^{* *} \\
(0.117) \\
0.484\end{array}$ \\
\hline $\begin{array}{r}\text { Linear Flexible Slope } \\
\text { R-squared }\end{array}$ & $\begin{array}{c}0.429 \\
(0.280) \\
0.495\end{array}$ & $\begin{array}{c}0.423 \\
(0.311) \\
0.459\end{array}$ & $\begin{array}{c}0.0598^{*} \\
(0.0316) \\
0.412\end{array}$ & $\begin{array}{c}0.203^{* *} \\
(0.0943) \\
0.498\end{array}$ \\
\hline \multirow[t]{2}{*}{ Quadratic } & $\begin{array}{c}0.628^{*} \\
(0.359) \\
0.494\end{array}$ & $\begin{array}{c}0.615^{*} \\
(0.365) \\
0.456\end{array}$ & $\begin{array}{c}0.105^{* *} \\
(0.0453) \\
0.404\end{array}$ & $\begin{array}{c}0.281^{* *} \\
(0.127) \\
0.485\end{array}$ \\
\hline & Panel B: & Varying & Bandwidth & \\
\hline Specification & $\begin{array}{l}\text { Affected } \\
\text { Persons }\end{array}$ & Fatalities & $\begin{array}{c}\text { Major } \\
\text { Incidents }\end{array}$ & $\begin{array}{c}\text { Total } \\
\text { Incidents }\end{array}$ \\
\hline \multicolumn{5}{|l|}{$-\mathrm{x}<\operatorname{rank} \leq \mathrm{x}$} \\
\hline $\begin{array}{r}x=10 \\
\text { R-squared }\end{array}$ & $\begin{array}{c}0.760^{*} \\
(0.447) \\
0.496\end{array}$ & $\begin{array}{c}0.853^{*} \\
(0.454) \\
0.458\end{array}$ & $\begin{array}{c}0.133^{* *} \\
(0.0614) \\
0.422\end{array}$ & $\begin{array}{c}0.312^{*} \\
(0.161) \\
0.484\end{array}$ \\
\hline $\begin{array}{r}x=9 \\
\text { R-squared }\end{array}$ & $\begin{array}{c}0.851^{*} \\
(0.481) \\
0.499\end{array}$ & $\begin{array}{c}0.889^{*} \\
(0.498) \\
0.465\end{array}$ & $\begin{array}{c}0.145^{* *} \\
(0.0660) \\
0.443\end{array}$ & $\begin{array}{c}0.316^{*} \\
(0.174) \\
0.487\end{array}$ \\
\hline $\begin{array}{r}x=8 \\
\text { R-squared }\end{array}$ & $\begin{array}{c}0.884^{*} \\
(0.523) \\
0.499\end{array}$ & $\begin{array}{c}0.933^{*} \\
(0.539) \\
0.468\end{array}$ & $\begin{array}{c}0.152^{* *} \\
(0.0724) \\
0.445\end{array}$ & $\begin{array}{c}0.326^{*} \\
(0.190) \\
0.491\end{array}$ \\
\hline Outcome Mean & 0.580 & 0.263 & 0.035 & 0.170 \\
\hline
\end{tabular}

Panel A produces the Donut Hole results - this tackles measurement error by dropping districts closest to the cutoff. Panel B varies the bandwidth close to the cutoff, where the bandwidth size is "x." The results pxesented are for the linear specification where the slope is flexible on either side of the cutoff. Controls include baseline averages of each dependent variable and police force changes. Unit of observation is district-month. "Affected Persons" indicates number of persons killed, injured, abducted or captured. "Fatalities" indicates total number of deaths. "Major Incidents" indicates number of 'Major Incidents' as coded by the SATP website. "Total Incidents" is number of total Maoist-related incidents. 
Table A.13: Intent-to-Treat (ITT) and Without Police Controls

\begin{tabular}{|c|c|c|c|c|}
\hline & Panel A: & ITT & & \\
\hline Specification & $\begin{array}{l}\text { Affected } \\
\text { Persons }\end{array}$ & Fatalities & $\begin{array}{c}\text { Major } \\
\text { Incidents }\end{array}$ & $\begin{array}{c}\text { Total } \\
\text { Incidents }\end{array}$ \\
\hline Linear & $\begin{array}{c}0.287^{* *} \\
(0.133)\end{array}$ & $\begin{array}{c}0.270^{* *} \\
(0.123)\end{array}$ & $\begin{array}{c}0.0470^{* * *} \\
(0.0176)\end{array}$ & $\begin{array}{c}0.124^{* *} \\
(0.0499)\end{array}$ \\
\hline R-squared & 0.489 & 0.445 & 0.393 & 0.480 \\
\hline $\begin{array}{r}\text { Linear Flexible Slope } \\
\text { R-squared }\end{array}$ & $\begin{array}{c}0.317^{*} \\
(0.166) \\
0.489\end{array}$ & $\begin{array}{c}0.309^{*} \\
(0.166) \\
0.445\end{array}$ & $\begin{array}{c}0.0486^{* *} \\
(0.0211) \\
0.393\end{array}$ & $\begin{array}{c}0.132^{* *} \\
(0.0602) \\
0.480\end{array}$ \\
\hline $\begin{array}{l}\text { Quadratic } \\
\text { R-squared }\end{array}$ & $\begin{array}{c}0.335^{* *} \\
(0.162) \\
0.489\end{array}$ & $\begin{array}{c}0.348^{* *} \\
(0.161) \\
0.445\end{array}$ & $\begin{array}{c}0.0578^{* * *} \\
(0.0215) \\
0.393\end{array}$ & $\begin{array}{c}0.129^{* *} \\
(0.0594) \\
0.480\end{array}$ \\
\hline & Panel B: & Without & Police & \\
\hline Specification & $\begin{array}{l}\text { Affected } \\
\text { Persons }\end{array}$ & Fatalities & $\begin{array}{c}\text { Major } \\
\text { Incidents }\end{array}$ & $\begin{array}{c}\text { Total } \\
\text { Incidents }\end{array}$ \\
\hline $\begin{array}{r}\text { Linear } \\
\text { R-squared }\end{array}$ & $\begin{array}{c}0.559^{*} \\
(0.298) \\
0.486\end{array}$ & $\begin{array}{c}0.499^{*} \\
(0.280) \\
0.430\end{array}$ & $\begin{array}{c}0.0945^{* *} \\
(0.0394) \\
0.378\end{array}$ & $\begin{array}{c}0.240^{* *} \\
(0.109) \\
0.446\end{array}$ \\
\hline $\begin{array}{r}\text { Linear Flexible Slope } \\
\text { R-squared }\end{array}$ & $\begin{array}{c}0.541^{*} \\
(0.310) \\
0.486\end{array}$ & $\begin{array}{c}0.510 \\
(0.315) \\
0.429\end{array}$ & $\begin{array}{c}0.0806^{* *} \\
(0.0382) \\
0.381\end{array}$ & $\begin{array}{c}0.209^{* *} \\
(0.106) \\
0.452\end{array}$ \\
\hline $\begin{array}{l}\text { Quadratic } \\
\text { R-squared }\end{array}$ & $\begin{array}{c}0.721^{* *} \\
(0.362) \\
0.485\end{array}$ & $\begin{array}{c}0.738^{* *} \\
(0.371) \\
0.425\end{array}$ & $\begin{array}{c}0.121^{* *} \\
(0.0486) \\
0.371\end{array}$ & $\begin{array}{c}0.261^{* *} \\
(0.133) \\
0.442\end{array}$ \\
\hline Outcome Mean & 0.580 & 0.263 & 0.035 & 0.170 \\
\hline
\end{tabular}

Panel A shows the Intent-to-Treat impacts (the reduced form results). Panel B shows the results without controlling for changes to the police force.

Controls include baseline averages of each dependent variable. Unit of observation is district-month. Regressions contain 3192 observations: 228 district-clusters (Phase 1 and Phase 2 districts) in 14 months xil 2 implementation.

"Affected Persons" indicates number of persons killed, injured, abducted or captured. "Fatalities" indicates total number of deaths. "Major Incidents" indicates number of 'Major Incidents' as coded by the SATP website. "Total Incidents" is number of total Maoist-related incidents. 
Table A.14: Other Specifications: Count Data and Difference-in-Differences

\begin{tabular}{|c|c|c|c|c|}
\hline & Panel A: & Count Data & & \\
\hline Specification & $\begin{array}{l}\text { Affected } \\
\text { Persons }\end{array}$ & Fatalities & $\begin{array}{c}\text { Major } \\
\text { Incidents }\end{array}$ & $\begin{array}{c}\text { Total } \\
\text { Incidents }\end{array}$ \\
\hline Linear & $\begin{array}{l}2.207^{* *} \\
(1.014)\end{array}$ & $\begin{array}{c}2.443^{* * *} \\
(0.881)\end{array}$ & $\begin{array}{c}2.552^{* * *} \\
(0.618)\end{array}$ & $\begin{array}{l}1.619 * * \\
(0.760)\end{array}$ \\
\hline Linear Flexible Slope & $\begin{array}{c}2.125^{* * *} \\
(0.733)\end{array}$ & $\begin{array}{c}2.306^{* * *} \\
(0.634)\end{array}$ & $\begin{array}{c}2.108^{* * *} \\
(0.483)\end{array}$ & $\begin{array}{l}1.105^{*} \\
(0.596)\end{array}$ \\
\hline \multirow[t]{2}{*}{ Quadratic } & $\begin{array}{c}2.503^{* *} \\
(1.066)\end{array}$ & $\begin{array}{c}2.466^{* * *} \\
(0.723)\end{array}$ & $\begin{array}{c}2.204^{* * *} \\
(0.551)\end{array}$ & $\begin{array}{c}1.368 \\
(0.931)\end{array}$ \\
\hline & Panel B: & Difference in & Differences & \\
\hline Specification & $\begin{array}{l}\text { Affected } \\
\text { Persons }\end{array}$ & Fatalities & $\begin{array}{c}\text { Major } \\
\text { Incidents }\end{array}$ & $\begin{array}{c}\text { Total } \\
\text { Incidents }\end{array}$ \\
\hline $\begin{array}{r}\text { Intent-to-Treat } \\
\text { R-squared }\end{array}$ & $\begin{array}{c}0.223^{*} \\
(0.132) \\
0.428\end{array}$ & $\begin{array}{c}0.108 \\
(0.0982) \\
0.395\end{array}$ & $\begin{array}{c}0.0154 \\
(0.0103) \\
0.359\end{array}$ & $\begin{array}{c}0.107^{* *} \\
(0.0512) \\
0.478\end{array}$ \\
\hline $\begin{array}{r}\text { Actual Treatment } \\
\text { R-squared }\end{array}$ & $\begin{array}{c}0.303^{* *} \\
(0.151) \\
0.345\end{array}$ & $\begin{array}{c}0.0970 \\
(0.101) \\
0.355\end{array}$ & $\begin{array}{c}0.0227^{*} \\
(0.0129) \\
0.319\end{array}$ & $\begin{array}{c}0.0556^{* *} \\
(0.0260) \\
0.445\end{array}$ \\
\hline Outcome Mean & 0.580 & 0.263 & 0.035 & 0.170 \\
\hline
\end{tabular}

Panel A shows the results using a Count Data Model. The model used in this table is the Zero-Inflated Poisson model, where the zeros are predicted using pre-treatment averages of the dependent variable. The results are very similar using Hurdle Models (Logit-Poisson). Panel B shows the Difference-in-Differences results. The Intent-to-Treat results assigns treatment status to districts who should have received NREGS, whereas the 'Actual Treatment' row assigns treatment status to districts that actually received NREGS.

Controls include baseline averages of each dependent variable. Unit of observation is districtmonth. Regressions contain 3192 observations: 228 district-clusters (Phase 1 and Phase 2 districts) in 14 months post-Phase 1 implementation and pre-Phase 2 implementation.

"Affected Persons" indicates number of persons killed, injured, abducted or captured. "Fatalities" indicates total number of deaths. "Major Incidents" indicates number of "Major Incidents' as coded by the SATP websitiei "Total Incidents" is number of total Maoistrelated incidents. 


\section{B A Citizen-Support Model}

We set up a theoretical model that incorporates the importance of citizens assisting the government by sharing information, although in practice this can also include other forms of assistance. While there are some models that stress the importance of citizen support, such as the models in Berman, Shapiro and Felter (2011) on counterinsurgency in Iraq and the Akerlof and Yellen (1994) study on street-gangs, our model differs from those in a number of respects that fit our context better. First, we allow insurgents to fight for territory, whereas the rebels' goal in the Berman, Shapiro and Felter model is only to impose costs on the government. Second, in our model civilians make their information-sharing decisions before rather than after the government and the insurgents move. Lastly, we consider how aggregate violence patterns may change dynamically.

The model describes the optimal strategies in the conflict by three players, the government, the Maoists, and the civilians. In the Indian context, the employment guarantee scheme was implemented across the country and prioritized poor districts regardless of their internal security condition in the assignment algorithm. Therefore, the decision about whether, and if so, how much, to invest in anti-poverty programs like an employment guarantee scheme is taken to be exogenous. ${ }^{37}$ There are $L$ identical locations in the country where the government fights for territorial control with the insurgents. In each location, the probability that the government gains control of the territory $p(m, v, i)$, depends positively on the amount of governmental military action $m$, negatively on the amount of Maoist violence inflicted upon the police $v$, and positively on the amount of information that the police has $i$.

Civilians (C) first choose how much information $i$ to share with the government to maximize their expected utility

$$
E U_{C}=b(i)-c_{C}(r(i))+p(m, v, i) u\left(y_{G}+g\right)+(1-p(m, v, i)) u\left(y_{N}\right)
$$

where $b(i)$ is the utility derived from the benefits of sharing information with the government, which may include both monetary and non-monetary components. ${ }^{38} c_{C}(r(i))$ measures the disutility from sharing information be-

\footnotetext{
${ }^{37}$ In other contexts, a number of economic and political economy factors will enter the government's objective function in addition to anticipated internal security benefits.

${ }^{38}$ The results are not sensitive to the order of moves as long as the rebels and the police move simultaneously, and the government expenditure is decided on before the civilians move. The order used in this model is related to the context - where civilians first decide on providing tip offs to the government, and the police then act on the information.
} 
cause Maoists may retaliate against civilians for sharing information based on a known retaliation function $r(i) . y_{G}$ and $y_{N}$ are the benefits civilians receive when their location is under government control or Naxalite control at the end of the period, respectively, and $u($.$) is the utility function for these ben-$ efits. $g$ is the extra benefit to citizens from governmental programs like an employment guarantee scheme. ${ }^{39}$

Overall, civilians therefore take into account both costs and benefits that arise directly from providing assistance to the government and the benefits provided by whoever is in power at the end of the period, which is also influenced by the level of information.

After civilians have made their decision, government troops and the insurgents simultaneously decide on their actions. The police $(G)$ decides how much military action $m$ to take against the Maoists to maximize the expected utility

$$
E U_{G}=p(m, v, i)-c_{G}(m)
$$

For simplicity, the government's expected utility from territorial control is assumed to equal the probability $p($.$) that the government gains control,$ whereas the disutility from military action is given by $c_{G}(m)$.

At the same time, the Naxalites $(\mathrm{N})$ determine how many attacks $v$ to plan against the government, maximizing their expected utility

$$
E U_{N}=[1-p(m, v, i)]-c_{N}(v)
$$

where $c_{N}(v)$ are the costs incurred from violence level $v$ and $1-p($.$) is the$ probability that the Maoists will be in control of the location at the end of the period. Additionally, the Maoists retaliate against civilians for working as police informers, where retaliation $r(i)$ increases with the amount of information and assistance provided to the police. ${ }^{40}$

Together, the decisions by government actors and insurgents determine the level of violence in a given location and the endogenous probability that the government gains territorial control. At the end of the period, a location either

\footnotetext{
${ }^{39}$ While some of the literature like Kalyvas (2006) sees territorial control as a precondition for collaboration, our model is built on the idea that the expected benefits from future territorial control by the government may induce civilians to support the government in the fight against insurgents. This support will be low if the probability of government control is very low, consistent with the idea that it is difficult for the government to receive citizen support if its position in the conflict is weak.

${ }^{40}$ The retaliation is used to prevent further sharing of information, which is something that is not captured in this one-period model. It is also possible to model retaliation as a decision taken simultaneously with the civilian's information sharing in order to capture the value of the 'threat' of retaliation.
} 
becomes controlled by the government or remains contested, and payoffs are realized. In the next period, the process is repeated in all locations that remain contested, whereas there is no further violence in government-controlled areas. Cost functions $c_{C}(),. c_{G}($.$) , and c_{N}($.$) are increasing and convex.$

The model can be solved by backward induction to find the pure-strategy subgame perfect Nash equilibrium. Once civilians have decided on the amount of information $i^{*}$ to share with the government, the government maximizes its expected utility, taking $i^{*}$ and the violence level $v$ chosen simultaneously by the Maoists as given. The first-order condition of (2) is therefore given by

$$
\frac{\partial p\left(m, v, i^{*}\right)}{\partial m}-c_{G}^{\prime}(m) \leq 0
$$

This equation pins down the best response function of military action $m^{*}$ for every potential violence level $v$ chosen by the insurgents. Since $c_{G}($.$) is$ convex in $m$ whereas $p($.$) is concave in m$, a unique maximum exists according to the Intermediate Value Theorem that satisfies the second-order conditions.

Similarly, the first-order condition for the Maoists is given by

$$
\frac{-\partial p\left(m, v, i^{*}\right)}{\partial v}-c_{N}^{\prime}(v)=0
$$

which implicitly traces out the best-response function of $v^{*}$ for every potential government violence level $m$. Assuming that $p($.$) is decreasing and$ convex in $v$, this once again satisfies the second-order conditions.

In equilibrium, both actors make correct predictions about the level of violence chosen by the other player, leading to a Nash equilibrium in each subgame given the level of $i^{*}$ where the best-response functions for the two players intersect. Assuming that $p_{m v}=p_{v m}<0,{ }^{41}$ it can be shown that $\frac{d m *}{d v}<0$ and $\frac{d v *}{d m}>0$ using the Implicit Function Theorem, which guarantees the existence of a unique Nash equilibrium.

We assume that government military action is more effective with access to more information $p_{m i}>0$, while more information could make Maoist attacks against the police less effective $p_{v i} \leq 0$. This, in turn, implies that according to the Implicit Function Theorem $\frac{d m *}{d i}>0$ and $\frac{d v *}{d i} \geq 0$, so more shared information by the civilians leads to higher levels of violence by both conflict parties. $^{42}$

\footnotetext{
${ }^{41}$ Intuitively, a given actor's effectiveness of violence on control over a location becomes lower the higher the violence of the other conflict party.

${ }^{42}$ For the police, the military action is complementary to the amount of information, and thus increases with more information. The rebels, however, fight harder to hold on to
} 
Civilians decide how much information to share with the government at the beginning of the period, knowing the best response and equilibrium violencelevel functions, which leads to the first-order condition

$$
b^{\prime}(i)-c_{C}(r(i))+\frac{d p}{d i}\left[u\left(y_{G}+g\right)-u\left(y_{N}\right)\right] \leq 0
$$

where $\frac{d p}{d i}=\frac{\partial p}{\partial m} \frac{d m}{d i}+\frac{\partial p}{\partial v} \frac{d v}{d i}+\frac{\partial p}{\partial i} \cdot{ }^{43}$ By the implicit function theorem, $\frac{d i^{*}}{d g}=$ $\frac{-\frac{d p}{d i} u^{\prime}\left(y_{G}+g\right)}{S O C}>0$. This implies that civilians will assist the police with more information or assistance when they receive governmental programs like NREGS. ${ }^{44}$

As discussed above, a higher level of shared information increases $m^{*}$ and $v^{*}$. Additionally, Naxalites also retaliate more against civilians since $r(i)$ is increasing in $i$. This means that overall violence in a given location rises after the introduction of the government program, and the impact will be greater for districts that do a better job of implementing the program.

The equilibrium decisions by civilians, insurgents and the government determine the probability $p^{*}$ that the government will gain control in a given location, or district, at the end of the period. Since all locations are identical, in expectation the number of contested territories $\ell_{t}$ will decrease over time according to the relationship

$$
\ell_{t}=\left(1-p^{*}\right) \ell_{t-1}
$$

After the conflict has lasted $\tau$ periods, the number of contested location is therefore: $\ell_{\tau}=\left(1-p^{*}\right)^{\tau} \ell_{0}$. Given the simplifying assumption in this model that violence in a location stops once the government gains control, the number of territories decreases over time until the war ends in period $T$ when $\ell_{T}=0$.

The improved information flow increases the equilibrium probability that the government gains control in a location, which will speed up the end of the conflict. With a higher government success probability more locations will fall under government control in a period than before, leading to the fewer contested territories in the next period. While violence in a given location

territory that is slipping away.

${ }^{43}$ Assistance and information increases the probability of police control if $\frac{\partial p}{\partial m} \frac{d m}{d i}+\frac{\partial p}{\partial i}>$ $-\frac{\partial p}{\partial v} \frac{d v}{d i}$.

${ }^{44}$ While the police force in practice largely consists of local officers whereas NREGS is a national program, implementation quality largely depends on local institutions. Zimmermann (2013b) finds, for example, that both the government parties as well as local incumbents regardless of party affiliation benefit from NREGS in areas where the program is implemented well in the 2009 general elections. This suggests that the people are aware that local institutions and personnel matter. 
has gone up, this effect means that the aggregate violence, averaged across locations, will fall over time as the government wins the war more quickly than it otherwise would have.

Overall, the model therefore generates a number of testable predictions about the impact of a government program like NREGS on the incidence of conflict. First, the introduction of NREGS increases insurgency-related violence in the short-run. In the longer run, violence falls. Second, the program increases the government's effectiveness in tracking down insurgents, so there are more police-initiated attacks. This also implies that insurgents should be more likely to die or to be injured/captured than before. Furthermore, civilians may be more affected by violence if the Maoists retaliate against them for sharing information. 